by Nancy McHenry Fletcher

8.

\title{
THE SEPARATION OF SINGAPORE FROM MALAYSIA
}
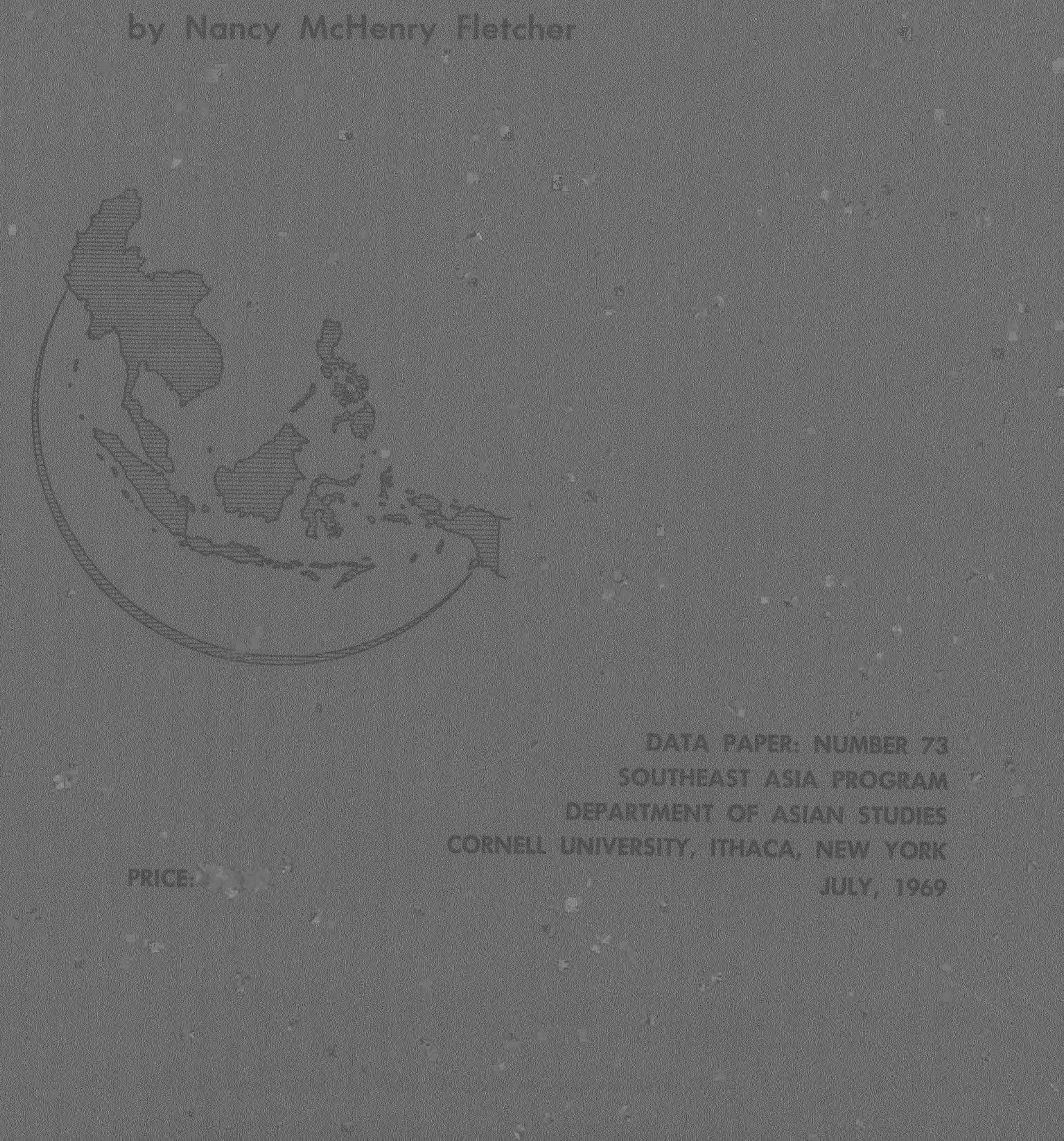

THE SEPARATION OF SINGAPORE

FROM MALAYSIA 
THE CORNELL UNIVERSITY SOUTHEAST ASIA PROGRAM

The Southeast Asia Program was organized at Cornel1 University in the Department of Far Eastern Studies in 1950. It is a teaching and research program of interdisciplinary studies in the humanities, social sciences and some natural sciences. It deals with Southeast Asia as a region, and with the individual countries of the area: Brunei, Burma, Camhodia, Indonesia, Laos, Malaysia, the Philippines, Thailand, and Vietnam.

The activities of the Program are carried on both at Cornell and in Southeast Asia. They include an undergraduate and graduate curriculum at Cornel1 which provides instruction by specialists in Southeast Asian cultural history and present-day affairs and offers intensive training in each of the major languages of the area. The Program sponsors group research projects on Thailand, on Indonesia, on the Philippines, and on the area's Chinese minorities. At the same time, individual staff and students of the Program have done field research in every Southeast Asian country.

A list of publications relating to Southeast Asia which may be obtained on prepaid order directly from the Program is given at the end of this volume. Information on Program staff, fellowships, requirements for degrees, and current course offerings will be found in an Announcement of the Department of Asian Studies, obtainable from the Director, Southeast Asia Program, Franklin Ha11, Cornel1 University, Ithaca, New York 14850 . 


\title{
THE SEPARATION OF SINGAPORE
}

FROM MALAYSIA

\author{
by
}

Nancy McHenry Fletcher

Data Paper: Number 73

Southeast Asia Program Department of Asian Studies Cornel1 University, Ithaca, New York July, 1969

Price: $\$ 2.50$ 
(C) 1969 CORNELL UNIVERSITY SOUTHEAST ASIA PROGRAM

$$
\begin{aligned}
& \text { First Printing, } 1969 \\
& \text { Second Printing, } 1971
\end{aligned}
$$


To Skip 
PREFACE

Mrs. Fletcher's monograph on Singapore's separation from Malaysia is the first substantial study of this important development in the international relations of Southeast Asia. It is also a study of pertinent aspects of the internal politics of Malaysia on the eve of the schism. She sets forth the very different expectations of Lee Kuan Yew and Tunku Abdul Rahman as to how the new Malaysian state should develop, and makes clear why their projections were so incompatible. In the process she assesses the economic, political and ethnic factors which in their combination tore the short-lived federal fabric apart. In her analysis of these factors her study is also instructive to an understanding of some of those forces which were later to emerge with such strength in Malavsia's recent (Nay 1969) elections.

As Mrs. Fletcher makes clear in her introduction, this study is a first effort at analysing an unusually complex situation and is not to be regarded as in any sense definitive. Nevertheless, she has provided, I helieve, a halanced and judiciously analyzed account which is the most comnrehensive vet puhlished, and for which hoth those who follow Southeast Asia's international relations and those interested in its domestic politics will he indehted.

Cenrge McT. kahin

Corne11 University

I thaca, New York

Ju1y, 1969 
ACKNOWLEDGMENTS

The author is especially grateful to Professor George McT. Kahin for his guidance, criticism, and encouragement throughout the early stages of the preparation of this study. She is grateful, too, to Miss Ruth McVey who, in the absence of Professor Kahin, kindly agreed to assist in the final stages of its writing.

The author would like to express her appreciation to the various members of the Southeast Asia Program at Cornell University for their aid and assistance. She is particularly indebted to $\mathrm{Mr}$. Michae $1 \mathrm{~B}$. Leigh, Miss Chan Heng Chee, and Mr. Zainal Abidin, a visiting Malayan scholar.

Certain members of the Washington, D.C., offices of the United States Department of State, the Malaysian Embassy, the United States Information Agency, and the International Bank for Reconstruction and Development are also gratefully acknowledged for their time and for the information they provided. 

TABLE OF CONTENTS

Page

INTRODUCTION . . . . . . . . . . . . . . . . 1

I. PRELUDE TO CONFLICT . . . . . . . . . . . . . . 4

I . THE ECONOMIC VARIANT . . . . . . . . . . . . . 11

The Common Market . . . . . . . . . . 12

Division of Singapore Revenue . . . . . . . 16

The Borneo Loan... . . . . . . . . . . 18

Other Financial and Economic Issues . . . . 20

iti. THE POLITICAL VARIANT . . . . . . . . . . 26

Background . . . . . . . . . . . 26

Constitutional Framework . . . . . . . . . . 29

The Singapore Election, 1963 . . . . . . . . . 31

The Malayan Election, 1964 . . . . . . . . 32

UMNO in Singapore . . . . . . . . . . . . . 40

The Singapore Riots . . . . . . . . . . . 42

Truce ... . . . . . . . . . . . . . 45

The Political Dispute, Continued . . . . . 46

IV. THE RACIAL VARIANT . . . . . . . . . . 56

Issues .... . . . . . . . . . . 57

Participants ............... 60

The Dispute... . . . . . . . . . . . 62

V. THE FOREIGN VARIANT . . . . . . . . . . . . 67

VI. CONTRIBUTING CONDITIONS . . . . . . . . . 72

Singapore Security . . . . . . . . . . 72

Other Factors . . . . . . . . . . . 77

CONCLUSION . . . . . . . . . . . . . . . 78

BIBLIOGRAPHY . . . . . . . . . . . . . . 81

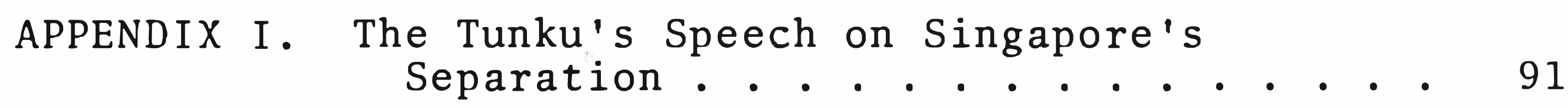

APPENDIX II. Proclamation of Singapore . . . . . . . 97 



\section{INTRODUCTION}

On September 16, 1963, after more than two years of discussion and preparation, the States of Malaya, Singapore, Sarawak, and Sabah joined together to form the federation of Malaysia. The motivations, objectives, and expectations tied up in the merger were as diverse as the land and people of the four units involved. Yet when Malaysia came into being, both Tunku Abdul Rahman, Prime Minister of Malaya, and Lee Kuan Yew, Prime Minister of Singapore, appeared to be deep1y committed to the concept of Malaysia and to the new state which they had created.

On August 9, 1965, the state of Singapore was separated from Malaysia. For the Tunku, the news of separation, which he announced to the Malaysian Parliament, was "the most painful and heart-breaking news I have had to break. . . "e For Lee, "it is a moment of anguish. A11 my 1 ife, my whole adult life, I have believed in merger and unity of the two territories. . . It broke everything we stood for."e

It is the purpose of this paper to investigate the nature of the tensions, pressures, and disputes which brought Malaysia from the hope of merger to the heart-break of separation. It is impossible to determine and relate every aspect of the divisive dispute between the Federal government and politicians of Malaya on the one hand, and the politicians and government of Singapore on the other. Moreover, the various elements of the conflict were so inter-related that any attempt to separate them for the purpose of analysis necessarily distorts them. This paper, then, is both incomplete and, in a sense, artificial. It is my hope, however, that it will help to make the conflicts which led to the separation of Singapore from Malaysia at least a degree more comprehensible.

Two basic premises concerning the split must be established at the outset. First, the break decision was made by the Tunku alone. Second, the leaders of Singapore did not desire the separation of their state from Malaysia.

1. From the Tunku's separation speech, Straits Times, August 10,1965 .

2. From Lee's press conference, Straits Times, August 10, 1965 . 
It is clear that members of the Tunku's inner-cabinet endorsed the break decision before it was made public.t ${ }^{3}$ It is clear, too, that the words and actions of the Malay "ultras" in the Tunku's own United Malays National Organization (UMNO), the dominant party in the ruling Alliance, helped to produce the environment in which the Tunku felt the break necessary. But it is exceedingly doubtful that either of these elements, as a unit or as individuals, had any direct part in the taking of the decision. A11 of the members of the inner-cabinet had worked with and under the Tunku for many years, and there is no evidence to suggest that any of them urged the Tunku toward separation.t Moreover, had the Tunku followed the admonitions of the Malay "ultras, $t$ ' he probably would have taken repressive action against the leaders of the Singapore government instead of removing the state from the federation. Indeed, one of the alleged leaders of the "ultra" faction, UMNO Secretary General Dato Jaffar Albar, resigned his party post following the break because of his disagreement with the Tunku on the separation issue.t $t^{5}$

The Tunku himself claimed that he had made the decision in late June, while convalescing in the London C1inic.t From a11 available evidence it would appear that when the Tunku returned to Kuala Lumpur on August 5, after eight weeks abroad, the break already was a reality in his mind, awaiting only official implementation.

As for Singapore, virtually all reports both before and after the break decision was made public clearly indicate that Lee Kuan Yew neither desired nor expected (at least at that time) that his island state would be cast off from the larger federation. On the contrary, Lee appears to have hoped and, indeed, expected that some accommodation could be made within the framework of the established federation of

3. See the interview with the Tunku reported in Sunday Times (Singapore), August 15, 1965 .

4. It was probably the lack of success of the conciliation efforts of Deputy Prime Minister Tun Abdul Razak, however, that led the Tunku to believe that the dispute had passed the point where reconciliation was possible.

5. See the report of Albar's press conference at which he commented,". . Malaysia without Singapore has become illogical." Straits Times, August 12, 1965.

6. Sunday Times (Singapore), August 15, 1965. 
Malaysia.i It remains, then, to investigate the nature of the conflict which led the Tunku to take his decision for separation despite apparent opposition to the move in both Malaya and Singapore.

Among the many variants of the dispute between the Central and Singapore governments and between politicians in the two states, three stand out as crucial. The clearest is the economic dispute which arose out of the financial and economic provisions of the Malaysia Agreement. The common market, the state-federal division of revenue, the Borneo loan, industrial and trade policies all became points of conflict in a battle which was partly personal, partly the result of divergent economic interests in the two states.

More central and more fundamental was the political conflict. Lee Kuan Yew's attempt to win a place for himself and his political ideas in the national political arena was resented and opposed by various factions in peninsular Malaya. But this political conflict was inextricably bound up with the racial or communal issue, which constitutes the third and most explosive element in the dispute. Hostile MalayChinese racial feelings in Malaya, latent for many years, were fanned to the point of flames by the multiplying recriminations growing out of a basic mistrust of each race by the other and out of the fear engendered by the "intrusion" of Singapore's primarily Chinese leaders into Malay-dominated peninsular politics. A fourth element in the dispute, less central than the three just mentioned, was the difference in foreign outlook and appeal of the two most prominent figures in the conflict, Tunku Abdul Rahman and Lee Kuan Yew.

Malaya and Singapore were bound together in the federation of Malaysia. Both of these states were and are unique and heterogeneous entities combining different races and different types of political and economic organization. But perhaps it is not too much of a distortion to say that within this western half of Malaysia, the issues which were to cause the greatest conflict and division--racial (Malay vs. Chinese), territorial (Malaya vs. Singapore), ideological (conservative capitalist vs. liberal socialist?), political (Al1iance Party vs. People's Action Party)--al1 found the champions of their opposing sides separated by the narrow strip of water between Singapore and Malaya. These 1 ines of conflict, drawn so many times in the same place, eventually broke the fibers holding the island state to the peninsula and ripped apart the fabric of the federation of Malaysia.

7. See Lee's news conference and interview reported in Straits Times, August 10 and 12, 1965. 


\section{CHAPTER I}

PRELUDE TO CONFLICT

The conflicts leading to the separation of Singapore from Malaysia are not fully understandable without some overview of both the major considerations which led to the desire for merger and the kind of union envisioned by each state. The idea of a Malaysia federation was not new. Historically, Singapore and Malaya had extensive political, economic, and social ties. When the Malaysian area came under British rule, Singapore became part of the Straits Settlement (including also Penang and Malacca), while Malaya proper was eventually divided into Federated and Unfederated States.

Singapore's first official separation from Malaya came in 1946 when the Malayan Union was formed (including Penang and all of peninsula Malaya), and Singapore was established as a separate Crown Colony. Since that time both British and local officials had, from time to time, proposed the "reuniting" of the two territories. Ties, particularly economic ties, remained strong, but inertia, apprehension, and preoccupation with more urgent concerns combined to make merger a future possibility rather than a present reality. In the early 1960's, however, certain pressing considerations caused the idea to be brought to fruition.

It seems clear that throughout the period before the Prime Minister of Malaya, Tunku Abdul Rahman, made his Malaysia proposal, Singapore leaders, particularly those in the People's Action Party (PAP), were consistently working toward merger while Malayan leaders were continually wary of Singapore's overtures. ${ }^{1}$ In the words of a Singapore Ministry of Culture publication hailing the Tunku's Malaysia proposal:

The politics of the P.A.P. directed towards building a genuine Malayan loyalty, the acceptance of Malay as the national language, the fostering of a Malayan culture, the consistent rejection of racial politics and of the ridiculous concept of an independent Singapore, and finally two years of persuasion and of argument with the Federation leaders bore fruit. $\stackrel{2}{2}$

1. See Milton E. Osborne, Singapore and Malaysia (Ithaca, N.Y., 1964), especially pp. 8-16. Also note Lee's speech reported in Straits Budget, May 3, 1961 .

2. Singapore Ministry of Culture, year of Fulfilment, June 1962 - June 1962 (Singapore, 1962), p. 45. 
The major reasons for the People's Action Party's dedication to the cause of merger were three. First, PAP leaders saw merger as the only possible solution to Singapore's severe economic problems. The Singapore economy was based primarily on entrepot trade. Malaya was the hinterland which produced rubber and tin "to keep our shop-window going.1" Merger was a form of insurance that the flow of exports and imports (including water) between Singapore and Malaya would not be cut off. But more important, Singapore's rapidly increasing population and her declining entrepot trade made rapid industrial growth a "matter of 1 ife and death.i' 1 Singapore's local market was not large enough to support efficient or numerous industries. Thus, if speedy industrialization was to take place, Singapore must find a wider market. Commented one Singapore government publication:

the real problems of providing for an adequate number of jobs for a fast rising population, of making a major improvement in standards of living, increasing the national output and the income per head can only be tackled when Singapore becomes part of a larger economic entity through merger with the Federation and Malaysia. $i^{5}$

The second reason for the PAP's dedication to merger was tied up with the problem of security. $1^{6}$ For several years, strikes, riots, and civil disorder had been common in Singapore. Leftist and communist activities had increased substantially over the past few years. This was distressing to the PAP in two respects. First, potential domestic and foreign investment, so crucial to industrialization, would be discouraged by the pervading labor unrest and social indiscipline prevalent in Singapore. It was felt that association with the larger Federation would provide for Singapore

3. Lee Kuan Yew, The Battle for Merger (Singapore, 1961), p. 4 .

4. Speech by Dr. Goh Keng Swee, Singapore Minister of Finance, reported in the Straits Budget, September 26, 1962 .

5. Singapore Ministry of Culture, Year of Fulfilment, p. 29 .

6. The word "security" is used in this study, as it is by officials of Malaysia and Singapore, in connection with "subversion" by leftist and communist elements. "Communist" and "leftist" are used here, as in Malaysia, quite loosely and at time synonymously. It is regrettable that the nature of the sources used prevents stricter and more accurate terminology. 
political stability to attract needed investment. $t^{2}$ But the political unrest was also distressing to PAP leaders because the growing communist strength seriously threatened the PAP's position as the ruling party in Singapore. With merger, communist strength would be diluted, enforcement of national security standards would be in the hands of a strong and avowedly anti-communist central government, and the PAP would have achieved its major policy objective and therefore mightt be able to win more favor with the Singapore voters.

A third reason for the PAP's desire for merger concerned the viability of Singapore as an independent state. The constitutional position of Singapore was scheduled to be reviewed by Britain in 1963, and a movement was afoot to secure independent status for the tiny island state. This, felt PAP leaders, would be a disaster. Commented Lee:

It would be utterly ludicrous for us--with our $1.6 \mathrm{mil}$ lion people--to try to chart our own way in this world. - . This is the age when man and his efforts must coordinate. Any country that has not got sufficient ballast, sufficient depth of economic strength, would fall by the wayside. $t^{8}$

An independent. Singapore, it was felt, would not be politically, militarily, or economically viable. Independence through merger was the only reasonable alternative.

Though PAP leaders continually emphasized the necessity and desirability of merger, it is clear that they did not intend Singapore to become simply a twelfth state of the Federation of Malaya. Many Singapore leaders--most vocally, the Prime Minister Lee Kwan Yew--considered Singapore to be the most important part of the proposed Malaysia. Commented Lee not long before the final agreements for merger were reached: "Calculate anyway you like, a peaceful happy prosperous Malaysia is only possible if we keep Singapore the centre of Malaysia."l Further, Singapore would retain a measure of her separate identity. Control of labor and education would remain in the hands of the Singapore government, and various sectional interests would be protected.t ${ }^{\circ}$ Com-

7. See the speech by Dr. Goh reported in the straits Budget, September 26, 1962 .

8. Straits Times, September 29, 1962 .

9. Straits Budget, July 3, 1963.

10. Certain Federation regulations applying to civil servants, workers, businessmen, merchants, etc., would not 
plete integration was the ideal, but it was considered to be impossible at that time.

Although PAP leaders intended that Singapore should be a very important, semi-autonomous part of the new federation of Malaysia, they also intended that there should be "absolute parity of treatment for everybody, whether in the Federation of Malaya, Singapore or the Borneo territories.ill The Malays would have to accept the Chinese and the Indians as equals, and, in the long run, all must have equal opportunities.

Before 1961, Malayan leaders, particularly Prime Minister Tunku Abdul Rahman, were hesitant seriously to consider merger with Singapore. This hesitance was primarily the result of what these leaders considered to be the political complexion of Singapore. First, the Chinese majority in Singapore was too "China-minded.1'z Second, Singapore politics were too leftist-oriented, too prone to control by communists. The Tunku feared Chinese domination and danger to Malaya's security should the two states come together. Commented the Tunku about the period before the Malaysia proposal was made:

I felt then that the conditions prevailing in Singapore, the trend of thought and the sentiments of the people of Singapore were entirely different from us in the Federation. The predominantly Chinese population in Singapore almost make the island a little China, and therefore the inclination of certain sections of the Singapore people is to follow closely the trend of political thinking in China.i ${ }^{3}$

In a speech to the Foreign Correspondents' Association of Southeast Asia in Singapore on May 27, 1961, the Tunku commented that Malaya could not stand alone, that a plan should be worked out to bring Malaya, Singapore, North Borneo, Brunei, and Sarawak closer together in political and

be extended to Singapore. See the Singapore Yang diPertuan Negara's (Head of State's) speech reported in Singapore Ministry of Culture, A Year of Decision (Singapore, 1961), p. 7 .

11. Lee, as reported in Straits Times, August 15, 1962.

12. Straits Budget, February 8, 1961.

13. Federation of Malaya, Department of Information, Malaysia, No. 2, April, 1962 (Kuala Lumpur, 1962), pp. $37-38$. 
economic cooperation. $t^{4}$ It was in this almost off-hand remark that the seeds of the federation of Malaysia were sown.

This "Malaysia proposal" indicated a significant change in the Tunku's attitude toward merger. The reasons for this change centered upon the growing fear that Singapore might become a communist stronghold on Malaya's doorstep, a "second Cuba." $t^{5}$ The Tunku argued that "extremist elements" and anti-colonial feeling were so strong in Singapore that when the constitution was reviewed in 1963, there would be on $1 y$ two choices: independence or merger. Independence for Singapore would be a disaster for Malaya, said the Tunku, for with independence there was a very real likelihood that extreme left wing elements or communists would gain power. Then, with the help of other communist powers, Singapore might try to overrun Malaya. The result would be a catastrophic war of East against West. "Therefore to prevent this most unhappy and disastrous state of affairs occurring, the only course open to us would be to accept Singapore as a member of the Federation of Malaysia." $t^{6}$

Introducing the motion on Malaysia and merger in Parliament in October, 1961, the Tunku commented:

While Singapore is under the British there is no threat of open action by the Communists which might endanger the peace and security of the Federation, but with an independent Singapore anything could happen. . .t .

Merger would prevent those who are Communist-minded from being able to align an independent Singapore with the Communist bloc. . .

National security demands it, our mutual economy demands it, and so do the people of both territories.t ${ }^{7}$

The Tunku's merger decision was closely linked with developments in Singapore and with the fear that Lee's PAP government was losing favor with the electorate. ${ }^{8}$ As the strength and activity of the leftist elements in Singapore

14. Straits Times, May 28, 1961.

15. Straits Budget, November 21, 1962.

16. Straits Budget, October 3, 1962.

17. Quoted in Lee Kuan Yew, Battle for Merger, pp. 127-130.

18. See Osborne, op. cit., pp. $40 \mathrm{ff}$. 
increased, the strength of the moderate faction of the PAP was weakening. The Hong Lim by-election, held a month before the Tunku made his "Malaysia proposal, 1 ' resulted in a shattering defeat of the PAP candidate. This seemed to be an indication of the direction of the sentiments of the Singapore people. The Tunku took heed.

In addition to the issue of security, the Tunku gave two other "reasons" for proposing merger of Singapore, Malaya, and the Borneo territories: to save Singapore from economic as well as political ruin, and to eradicate colonialism in the area through constitutional processes.19 But it is evident that the fear of communist ascendancy in Singapore was the primary reason for the proposal. Said the Tunku, "We can al1 see the threat of the Communists. If I did not see this danger I would not be bothered with the other territories like Singapore, Sarawak, Brunei and North Borneo.i'ín

Like Lee, the Tunku did not envision complete merger of Singapore and Malaya, at least for the present. He spoke of a "partnership" on the same order as that between the United Kingdom and Northern Ireland. ${ }^{21}$ The Tunku clearly intended Singapore to enjoy a measure of local self-government and autonomy in nearly all local matters. He emphasized the necessity of providing protection for the interests of the people of Malaya, including the continuation of Malay privileges, ${ }^{2} 2$ but he ridiculed the idea that Malaysia would mean Malay domination..$^{3}$

The Tunku, then, envisioned a Malaysia not far different from the old Malaya. Singapore would remain somewhat aloof, and the political and social character of Malaya would be maintained. Above all, Malaysia would, like Malaya before her, be a model of racial harmony and cooperation. Said the Tunku," . . it is not a Mighty Malaysia I have in mind, but a Happy Malaysia." ${ }^{4}$ And again, prophetically,

19. Straits Budget, August 21, 1963.

20. Straits Budget, March 21, 1962.

21. See the Tunku's speech in Battle for Merger, pp. 128130 .

22. Ibid., p. 129 .

23. Straits Budget, August 29, 1962 .

24. Straits Times, Ju1y 19, 1961. 
- . I firmly believe in peace and racial harmony, and I will fight any element that aims to destroy them. . . i If in merger with Singapore there is likely to be trouble and bloodshed, I would rather leave Singapore alone in spite of the potential danger that an independent Singapore would bring to the Federation..$^{5}$

25. Straits Budget, Apri1 4, 1962. 
CHAPTER I I

THE ECONOMIC VARIANT

Negotiations concerning the final terms under which Singapore would join Malaysia began early in 1963 and continued, with intermittent flare-ups, until the climactic crisis and the final signing of the Malaysia Agreement in London in early July, 1963. By far the hottest issue in these negotiations was the financial or economic issue. It was over economic questions that personal animosities between Malayan and Singaporean politicians, which were to play such an important role in the subsequent progress of the dispute, first showed their virulence. Lee Kuan Yew and Singapore Finance Minister Goh Keng Swee had numerous bitter exchanges with Malayan Finance Minister Tan Siew Sin. The cause of the conflict was not always simply the varying economic interests of the states involved. Personal and party differences as well as political considerations played a large role in the dispute. The bitterness which surrounded the bargaining left wounds which did not heal during the two years of merger.

By mid spring, 1963, it was clear that both Singapore and Malaya desired union under terms which were not easily acceptable to the other.i Conflicting demands concerning the establishment of a common market, Singapore's financial contribution to the Central government, a loan for Borneo deve1opment, and other issues, brought the talks to a virtual standstill in the late spring of 1963. The dispute reached such a state that Malayan Chinese Association Senator T. H. Tan warned that if the situation became much worse, he would move in the Senate that the Federation abandon all idea of merger so long as the PAP was in power..$^{1}$ In mid June, the Tunku offered his "final terms" and requested a reply from Lee within 48 hours. The Singapore Prime Minister replied, and certain of the issues appeared to have been resolved, but some of the major problems remained.

From personal and political motivations, Lee continued to push a hard bargain. He felt it necessary to win, for Singapore, the best possible terms, not only in order to improve his state's position, but also to boost his own and his party's political stature in the eyes of the Singapore electorate in order to secure badly needed popular support.

1. Malayan Bulzetin, 17:1, May 25, 1963. 
The nature of the man made compromise difficult, contention natural. Certain that Malaya's fear of a communist takeover in Singapore and her open commitment to the concept of Malaysia would prevent her calling off the proposed union, Lee argued from a position of strength.t ${ }^{2}$

The Tunku refused to go to London for the signing of the merger agreement until all the details of the terms of merger had been worked out and agreed upon. With other representatives of Malaya and Singapore in London for the terminal negotiations, Malaya made her "final offer." The Tunku, in Malaya, wired his chief negotiator, Deputy Prime Minister Tun Abdul Razak, to "break off the talks and return home" if Malaya's demands were not met. $t$ After arduous discussions, agreement was finally reached. Tun Razak wired the Tunku to fly to London, and the terms upon which Singapore would merge with Malaya were officially endorsed. This Malaysia Agreement, signed in London on July 9, 1963, set the framework for the financial dispute which continued through the next two years.

\section{The Common Market}

To Singapore, Malaysia meant, above all, a common market which would provide a wider, duty-free market for her indus trial products.t The idea of a common market between Malaya and Singapore had been proposed by Singapore Finance Minister Goh Keng Swee in 1959, and talks on the subject, between the Singapore and Malayan governments, had been held off and on since $1960 . .^{5}$ Yet in these early years, virtually no progress was made. With the proposal for Malaysia, Singapore's hopes for the establishment of a common market were revived. The World Bank's Rueff Commission, which investigated the economic aspects of Malaysia during 1962 and 1963, strongly recommended the formation of such a common market, $t$ and

2. See Lee's statement concerning the "final terms" in the Straits Budget, June 26, 1963.

3. The Guardian, July 5, 1963.

4. For a brief discussion of Singapore's economic interest in Malaysia see Denis Warner, "Singapore and Malaysia: A Divorce of Inconvenience, $t^{\prime}$ The Reporter (April 7, 1966), pp. $44-46$.

5. Straits Budget, May 31, 1961 .

6. See International Bank for Reconstruction and Development, Report on the Economic Aspects of Malaysia (Kuala Lumpur, $1963)$, pp. 41-61. 
was clearly Singapore's primary economic interest throughout the financial negotiations for merger. Commented one high Singapore official,i". . . one of the major reasons for merger was the resolution of Singapore's economic problems. - . a common market is of the essence of merger. . . "I

Malaya seemed not particularly concerned with the common market. Though agreeing in principle to the desirability of such a market, Malayan officials were not at all anxious to make a definite commitment on the subject. Lee, on the other hand, demanded that provisions for the common market be written into the constitution. On such a vital issue, Lee argued, Singapore could not rely upon the word of Malayan officials: ". . i. we have got to have this all written down on a piece of paper. . . " "8

With the final arrangements, Singapore appeared to have achieved its goal. According to Annex $J$ of the Malaysia Agreement:

The Federal Government . . i shall progressively establish a common market in Malaysia for all goods or products produced, manufactured or assembled in significant quantities in Malaysia, with the exception of goods and products of which the principal terminal markets 1 ie outside Malaysia. ${ }^{9}$

A Tariff Advisory Board was to be set up to assist with the formation of the common market and to recommend products to be included in it. i $^{\circ}$

But this basic agreement did not put an end to the wrangling, for in the two years of merger, 1ittle was done to implement the plans for the common market in which Singapore had such a vested interest. The Tariff Advisory Board finally was established in July of 1964, and by the time of the break it had published two lists of goods to be included

7. Straits Budget, Ju1y $10,1963$.

8. Straits Budget, June 26, 1963.

9. Malaysia: Agreement Concluded between the United Kingdom of Great Britain and Northern Ireland, the Federation of Malaya, North Borneo, Sarawak and Singapore

(Cmd. 22 of 1963) (Singapore, 1963)--hereafter cited as Malaysia Agreement--Annex J, p. 226.

10. Ibid., pp. $226-227$. 
in the common market;il but any concrete steps toward the harmonization of duties or the actual establishment of the common market had yet to be taken.

Singapore felt that the Central government was deliberately dragging its feet since Singapore, with a more highly developed industrial sector, had more to gain from the wider free market. Clearly, the Federal government was in no hurry to establish a common market. Malaya, like Singapore, was vitally interested in the development of industry, to balance her reliance on the export of primary products it ${ }^{2}$ Tariffs on good imported from Singapore (where labor costs were lower and materials cheaper) helped to protect some of Malaya's own fledgling industries. An international finance official speculates that Kuala Lumpur did not want the common market to be established before a national industrialization policy had been worked out, for fear that it would lead to an even greater industrial imbalance between Singapore and the other states of the federation. Yet, he noted, little was being done to formulate such a national industrialization policy. 13

The Central government explained the slow progress of the common market in many different ways. In mid 1964, Tan Siew Sin emphasized the Central government's concern lest the common market cause painful changes in Singapore's economy.1 ${ }^{4}$ Early in 1965 he stated that if Singapore wanted the common market it would have to accept all import duties then in effect in Malaya.i ${ }^{5}$ Eventually the argument over the common market became entangled with another economic dispute between the Central and Singapore governments. An appendix to the King's Speech in Parliament in May, 1965, noted the

11. The Singapore government seemed satisfied with the 1 ists themselves if not with the speed with which they vare drawn up and implemented. There appears to have bein no significant criticism of the lists either by Singapore or by Malaya. Indeed, interest in them seemed slight. See the criticism expressed by Tariff Advisory Board Chairman L.iA. D. Williamson reported in Straits Budget, December 16, 1964.

12. See Osborne, op. cit., pp. 50-51.

13. Personal interview with an official of the International Bank for Reconstruction and Development in Washington, D.C., Apri1 21, 1966 .

14. Straits Budget, June 17, 1964 .

15. Straits Times, February 15, 1965. 
delay in the implementation of the common market but added,

It should be appreciated, however, that the present arrangement for dividing Federal revenue in Singapore between the Central and State Governments make the development of a common market more difficult and consideration will have to be given to their alteration if rapid development of the common market is to be achieved.i 6

Singapore leaders, on the other hand, felt that they had agreed to the financial terms in return for the establishment of a common market. ${ }^{17}$

Shortly before separation, the dispute over the common market reached its climax. In a speech to the University of Singapore Economic Society, Tan Siew Sin commented that a common market was more than just a technical and economic proposition, that it was a political proposition, and the "right spirit" necessary for its implementation seemed to be lacking. He noted three major problems in implementing the common market agreement. First, the common market would interfere with entrepot trade in Singapore and thus must be initiated slowly in order not to create too great an economic problem. Second, the Central government had a duty to promote balanced industrial development in Malaysia, and the quick initiation of a common market might simply accentiate the present unbalanced development, giving great advantage to Singapore at the expense of the other territories. And third, the Central government had to explore every possible method of closing the gap between revenue and expenditures caused by the increasing defense costs. Since Singapore refused to pay its "fair share" and the remaining states therefore had to pay extraordinarily large shares, certainly the Central government could not take a step that would be to the economic advantage of Singapore at the expense of the other states..$^{18}$

Dr. Goh quickly replied with a list of instances of "the absence of the right spirit" in the Central government.i. 9 Lee commented, just two weeks before separation, that if

16. Straits Budget, June 2, 1965 .

17. See Lee's letter to the Tunku, published in Straits Budget, Ju1y 31, 1963.

$18 \alpha$ Straits Times, Ju1y 18, 1965a

19. Straits Times, Ju1y 20, 1965. 
Singapore "does not benefit economically from Malaysia, and if the common market is not set up as laid down in the Malaysia Agreement, then Malaysia is meaningless."20 Clearly Singaporeis ambition of a common market was not to be realized immediately nor without difficulty.

\section{Division of Singapore Revenue}

The amount of Singaporeis contribution to the Federal government was another focus of dispute throughoutithe negotiations, and even until the eve of separation. During the early talks, the Central government demanded a specified percent of the revenues collected in Singapore while Singapore offered a yearly lump sum as payment for federal services in the island state.. ${ }^{1}$ During the final discussions in London in July, 1963, Malaya asked for 40 percent of the revenue collected in Singapore while the Singapore government held out for 39 percent and the promise of a common market. This dispute over the division of Singapore revenue was among the hottest during the final hours of negotiation.

Under the final arrangements, in exchange for Malaya's acceptance of the idea of a common market, Singapore agreed that

A11 revenues collected in Singaporei[with some minor exceptions] . i shall be divided between the two Governments and paid to them at least once in every year, in the proportion of 60 per cent to the Singapore Government and 40 per cent to the Federal Government.2 ${ }^{2}$

This arrangement was subject to review and revision from December 31,1964 , and every two years thereafter.

One international economist close to the situatio. suggests that Tan Siew Sin proposed the 60/40 arrangement oily after the Tunku urged that merger not be further delayed, and in anticipation of the early revision of the arrangement to make it more favorable to the Federal government. Subsequent events lend credence to this view. In December, 1964 , in connection with the Federal Budget, Tan Siew Sin announced

20. Straits Times, July 22, 1965.

21. Quarterly Economic Review: Federation of Malaya, Singapore, British Borneo Territories, No. 42 (June, 1963), p. 2 .

22. Malaysia Agreement, Annex J, p. 228. 
that he wanted to review the financial arrangements between the Singapore and Central governments so that Singapore would give more of its revenue (perhaps 60 percent) to the Centra1 government. He noted the rapidly increasing defense spending made necessary by Indonesian Confrontation and argued that Singapore's tax burdens were the lightest in the federation. ${ }^{3}$ Lee snapped backi

No argument, no nothing. Give him? What for? In order that the poor in Singapore pay taxes so that the rich in Malaya need not pay any? When they cannot answer you, they get their backbenchers to shout at you and threaten you. . i we will never be intimidated. $i^{4}$

In July of 1965 , Tan Siew Sin renewed his demand that Singapore increase its contribution to the Central government.i In a veiled threat he explained that the Central government had to explore every possible way of closing the budget gap and that it might be tempted to divert as many plants and factories as possible away from Singapore to other parts of the federation in order that the Central government receive more than 40 percent of the revenues derived from them..$^{5}$

Singapore Finance Minister Dr. Goh Keng Swee countered with the claim that 30 percent of Singapore revenue would be more than sufficient to meet Federal expenditures in Singapore. ${ }^{26}$ Late in July, Goh made public a letter written to him by Tan in November, 1964. Goh offered this letter as proof that Tan had requested the continuation of the original $60 / 40$ arrangement for another two years. The Federa1 Treasury replied (and its case was well supported by the text of the original letter) that the letter proposed the existing arrangements be allowed to continue until the end of 1965, by which time the Central and Singapore governments would be in a better position to assess their financial and economic positions. 27

Dr. Goh, in a letter to the straits Times, stated his government's position on the financial issue. He said that

23. Straits Times, December 3, 1964.

24. Straits Times, December 5, 1964 .

25. Straits Budget, Ju1y 28, 1965 .

26. Malaysian Mirror (Singapore), July 31, 1965.

27. Straits Budget, August 4, 1965. 
the increase in defense costs had been anticipated in the original agreements, and that Singapore's contribution was more than adequate in the 1 ight of her special position in the federation. He pointed to Singapore's autonomy in edut cationt labort and certain other areas which required substantial state expenditures. Similar expenditures did not have to be made by other state governments which lacked comparable autonomy. If the principle was to be invoked that the richer states should pay more than the poorer states, said Goh, there would be a constitutional rearrangement to give Singapore her rightful 60 parliamentary seats. ${ }^{8}$

It was reported in late July that the Central and Singapore governments had decided to submit to World Bank arbitration the question of apportionment of federal revenue colt lected in Singapore, $t^{9}$ but at the time of separation, polemics on this issue continued.

The Borneo Loan

Another point of conflict in the negotiations for merger and in the months that followed was the financing of development projects for the Borneo states of Sabah and Sarawak. Throughout the negotiationst Malaya had urged Singapore to give $M \$ 50$ million to the Central government to be used for development in the Borneo states. Singapore officials argued for a loan, rather than a gift, saying that Singapore was too poor to afford the role of Santa Claus and give $M \$ 50 \mathrm{mil}$ lion to the Central government as an "entrance fee" to Malaysia.t $t^{30}$

The final agreement provided for a Singapore loan of M\$150 milion to the Federal government for Borneo development. The loan was to be repaid over 15 years, but $M \$ 100$ million was to be free of interest for the first five years while the remaining $M \$ 50$ million was subject to interest at current market rates. The loan was to be drawn in equal annual installments over a period of five years, beginning in $1964 . t^{3}$

28. Straits Budget, August 11, 1965. The calculation of 60 seats probably was based on the ratio of population to seats alloted in the Borneo states.

29. Straits Budget, Ju1y 28, 1965.

30. Straits Budget, Ju1y 3, 1963.

31. MaZaysia Agreement, Annex J, pp. 229-230t 
Not included in the Malaysia Agreement, but the cause of considerable subsequent bickering, was the agreement between the Tunku and Lee negotiated at the last minute in London in July, 1963, and typed and signed on the back of an envelope. This rider provided that 50 percent of the 1 abor employed on projects in Sabah and Sarawak supported by Singapore funds, must come from Singapore. $i^{2}$ The labor stipulation probably was seen by Singapore as a means for relieving its chronic unemployment problem, and perhaps also as a weapon in future bargaining..$^{3}$

The Singapore government paid no part of the loan to the Federal government for the development of the Borneo states. $i^{34}$ To Singapore, the Borneo loan was tied up with the common market agreements, and Kuala Lumpur's foot-dragging on the latter was sufficient justification for Singapore's foot-dragging on the former. Then too, Singapore insisted, in the face of strong opposition by Tan Siew Sin, that the interest rate on the loan be fixed by the World Bank.is Moreover, the problem of the use of Singapore 1 abor in the Borneo projects never was resolved..$^{36}$

32. Straits Budget, July 31, 1963. Sir Donald Stephens, leader of Sabah, subsequently maintained that the agreement he had signed contained no such labor stipulation and that his country, therefore, was not bound by it.

33. One official of the World Bank, close to leaders on both sides of the dispute, argues that Lee realized that Singapore workers would be hesitant to go to Borneo and that the Borneo states would be hesitant to accept them. According to this source, Lee pushed the labor stipulation because of its possible usefulness as a rationale for Singapore's not implementing the loan agreement until other economic agreements were implemented to its satisfaction.

34. Personal interview with World Bank official, op. cit.; see also Tan Siew Sin's statement in Straits Budget, Ju1y 21, 1965 .

35. Straits Times, Ju1y 22, 1965 .

36. Dr. Goh reported late in 1964 that 8,000 Singaporeans had indicated their willingness to work in Borneo, but there was no subsequent indication that arrangements had been made for their actual employment in Sarawak or Sabah. See Straits Times, November 25, 1964. Again and again, the failure to fulfill the labor stipulation was given by Singapore officials as the reason for withholding the loan. See, for example, Straits Times, July 19 and 20,1965 . 
The Federal government felt itself unable, alone, to implement the vast development projects, promises of which had helped to woo the Borneo states into the federation, without seriously curtailing development projects in Malaya. Its bitterness was perhaps best expressed by Tan Siew Sin when he commented that he would welcome a federation of the three S's (Singapore, Sarawak, and Sabah) as an alternative to the established Malaysia because then Singapore would have to take over the financial and economic burden of the development of Sarawak and Sabah. ${ }^{7}$

Other Financial and Economic Issues

A number of other economic issues proved to be sources of friction during the two years Singapore and Malaya were joined in Malaysia. The issue of industrialization and pioneer status was one of the bitterest. Drior to merger, both Malaya and Singapore awarded to certain firms certificates of pioneer status under which the industry concerned was entitled to a five-year tax holiday and certain other concessionsa According to an Annex to Annex J of the Malaysia Agreement, pioneer certificates granted by Singapore were to be subject to the approval of the Federal Minister of Finance $\alpha$ A political dispute centered around the Central government's use of this authority.

Perhaps in anticipation of future difficulties with the Central government over these certificates, the Singapore government, between mid August and September 16, 1963, issued 77 pioneer certificates to Singapore firms. $a^{3}$ With the formation of Malaysia, however, the Central government's use of its authority over pioneer certificates was more restricted than Singapore's had been. Few if any nioncer status cor. tificates were granted to Singapore conceans after the formation of Malaysia. $z^{9}$

37. Straits Budget, July 21, $1965 \alpha$

38. Straits Times editorial, March 5, $1965 a$

39. It is difficult to ascertain whether any certificates were awarded to Singapore firms during the period from September 16, 1963, to August 9, 1965. Malcolm J. Pur$v$ is, in his paper "The Economic Implications of an Independent Singapore," presented at the Center for Southeast Asian Studies, Northern Illinois University, October, 1965 , p. 9, reports that no pioneer certificates were awarded in 1964. Other sources are ambiguousa It 
Some sources claim that the Federal government was concerned over the disproportionate share of foreign industrial investment taken by Singapore since merger, feared that the mainland could not compete with Singapore in attracting new industries, and so found it necessary to 1 imit the number of certificates awarded to Singapore firms in an attempt to redress the balance. Dr. Goh accused the Central government of trying to entice investors into Malaya instead of Singapore in the hopes of curtailing Singapore's industrial progress.t.

Trade was another focus of conflict in the federation. In August, 1964, the Singapore government restricted the import of goods from the Netherlands (because of her support for Indonesia) and from Britain (because of a disagreement over textile quotas). Although the Federal cabinet endorsed the Singapore moves, these unilateral acts by a member state of the federation did cause some concern among Federal

government officials.t In May, 1965e another minor dispute arose over Singapore's non-compliance with a Federal ban on imports from South Africa.

The major trade dispute, however, concerned the British quota for textile goods from Malaysia. In the words of one observert

the dispute epitomises the degenerating relationship between Kuala Lumpur and Singapore, the growth of mistrust as to each other's intentions, the lack of communication between the leaderships to overcome this mistrust. $t^{2}$

Briefly, the British government had announced in 1964 that it would not renew its quota for Singapore textiles but instead would issue one quota for all of Malaysia. The portion of the new quota tentatively offered to Singapore was substantially below that of previous years. A few months after the British announcement was made, Dr. Goh threatened

is safe to say, however, that at the very most, there were few pioneer certificates granted to Singapore firms during this period.

40. Straits Times, March 22, 1965.

41. Times (London), August 27, 1964.

42. Harvey Stockwin, "Broken Threads in Malaysia,t' Far Eastern Economic Review, 48: 119, Apri1, 1965. This article presents a concise discussion of the dispute. 
to ban British goods from Singapore, claiming that the dispute over Singapore's export of textiles to Britain had prevented the establishment of 50 factories and the loss of 10,000 potential jobs.t. $t^{3}$

Negotiations among Britain, Malaysia, and Singapore began in November, 1964 , and continued intetmittently for several months. In February, Singapore's National Trades Union Council threatened to refuse to handle British goods in Singapore if the British Board of Trade did not reconsider its restrictive import quotas on Singapore textile goods. Union leaders claimed that a number of factories had had to close down and thousands of workers had lost their jobs due to the British action. $t^{44}$

On March 21, 1965, Dr. Goh Keng Swee announced publicly that the talks with the British had collapsed, but he emphasized that

The collapse was not due to any deadlock between the British and ourselves. It arose from differences between the Central and Singapore Governments as to how the latest British proposal is to be handled. $t^{4}$

The British had offered a quota of 9.8 million square yards of woven textiles and an additional $7.6 \mathrm{million}$ square yards of made-up goods. They had, in addition, agreed to license al1 of Singapore's existing contracts up to March 1, 1965.46 The Central government had claimed for the states of Malaya the greater portion of the new quota for made-up goods. Singapore leaders strongly protested the usurpation of quotas they felt were intended for Singapore. They noted the scarcity of textile factories in the states of Malaya and the number of such factories in Singapore which were in serious straits because of lack of work. This was but the last, Dr. Goh complained, in

a series of actions taken by Kuala Lumpur which had the effects of damaging Singapore's industrial progress. It is clear that the Central Government of Malaya in its relations with Singapore considers itself not the Government of Malaysia but the Government of the States

43. Malaysian BulZedin, 18:4, August 26, 1964.

44. Straits Times, March 1, 1965.

45. Straits Times, March 22, 1965.

46. Quarterly Economic Review, No. 50 (June, 1965)ţ p. 3. 
of Malaya. Singapore is considered not as a constituent State of Malaysia but as a dangerous rival to be kept down at a11 costs.e.t

The Prime Minister's Department replied that on the basis of the Central government's proposals, Singapore would have nearly twice the textile quota of Malaya. The statement argued that it was the duty of the Central government to see that there was balanced development in all the states of Malaysia, and that the distress in the textile industry in Singapore was simply a result of the island's own injudicious industrialization policies. e $^{8}$

The dispute quickly degenerated into a political feud. The Central government maintained that dealings with other countries were on the federal list of powers and thus the decision in the matter rested with the Central government.e 9 Goh replied that he had received a letter from the British High Commissioner stating that British offers must be agreed to by both the Central and the Singapore governments.e $0^{0}$ The Tunku decried the bringing of the textile dispute into the open, claiming that "the Singapore Government is playing into the Communests' hands. Only the Communists will benefit by this." $e^{1}$ Education Minister Khir Johari commented picturesque 1ye

Apparently the idea is to give the people of Singapore the impression that the Central Government is made up of people who are jealous of Singapore's prosperity and who, like vultures are only waiting to catch the people of Singapore by the throat and squeeze the life out of them. 52

In the heat of the political feud, the point of the dispute seems to have been forgottene

Two other economiceissues warrant brief mentione In November, 1964, the Budget of the federation of Malaysia was

47. Straits Times, March 22, 1965.

48. Straits Times, March 23a 1965.

49. Straits Times, March 25, 1965.

50. Straits Times, March 29ę 1965e

51. Straits Times, a March 30, 1965.

52. Straits Times, April 19, 1965e 
introduced in Parliament by Finance Minister Tan Siew Sin. Defense expenditures necessitated new taxes, and the Federal government proposed a one-half percent turnover tax on gross earnings of a11 trades and businesses, and a two percent payrol1 tax. $t^{5}$ Lee Kuan Yew opposed the new taxes, claiming that Singapore had not been consulted and that the new taxes would work "completely inequitable" results, falling with greatest force on the "have nots." $t^{4}$ His partyts economic reasoning clearly outshone that of Federal financial officers, and a bitter debate ensued. The Federal leaders were particularly irate since, with the $60 / 40$ division of revenue, Singapore would get more of the new tax revenue than would the Federal government. Judging by their reaction, the A11iance Party leaders did not consider the PAP attack as being of the same nuisance character as the opposition they had faced previously in Parliament. They appeared shaken by the real or imagined threat. When introducing the Budget in the Senate, Tan Siew Sin claimedt

the sole remaining area of criticism now comes from the Communists and their fellow-travellers--the Singapore Government and the PAP and the PAP-dominated Singapore National Trades Union Congress. But their objections are clearly and largely motivated by political considerations. . tt. It is apparently their intention to incite the populace there to action, perhaps even violent action, in order to bring the Central Government to its knees.t.

Finally, dispute arose over the closing the Bank of China branch in Singaporet Tan Siew Sin announced in Parliament in late December, 1964, that the Central government intended to close the Bank of' China at some future date. $t^{56}$ Tan stressed the security risk involved in allowing the Bank to continue and claimed that communist funds reached the PAP through the Bank of China and that the PAP was sending out money through the Bank of China for safe-keeping abroad.t $t^{5}$ Lee Kuan Yew argued that the closure of the Bank might result in a consfderable reduction in overall trade with China and would produce economic hardship in Singapore. He accused

53. Straits Times, November 26, 1964.

54. Straits Times, December 1, 1964.

55. Straits Times, December 31, 1964.

56. Ibid.

57. Straits Times, January 1, 1965. 
the Central government of breaking an understanding made before mergeree ${ }^{5}$

By July, 1965, the dispute had become so irritating that the Tunku interrupted his convalescence in London to issue a statement emphasizing the security threat posed by the bank and saying that the Central government would be willing to reconsider the status of the Bank of China only if its directors would sever all ties with Peking; otherwise the bank would have to close. $e^{59}$ The Bank Negara Malaysia took over the Bank of China on August 5, to supervise the winding up of its business, and the bank was scheduled to close for good just five days after the split was announced.e ${ }^{6}$

58e Straits Times, June 24, 1965. Tan Siew Sin is reported to have said in Parliament in 1963 that even though the Malayan Banking Ordinance prohibited the operation in Malaya of banks with 50 percent or more of their capital owned by foreign governments, when the local Banking Ordinance was extended to the new states in Malaysia, all banks which could operate under the state's laws would be allowed to continue to function. Straits Budget, December 25, 1963.

59. Straits Times, July 7, 1965.

60. Straits Budget, August 11, 1965. 


\title{
CHAP TER I I I
}

\author{
THE POLI TICAL VARIANT
}

The conflict of the ambitions, ideologies, and priorities of the key political organizations and leaders in Singapore and Malaya was the most complex and probably the most central factor in the dispute which led to the separation of Singapore from Malaysia. The issues in conflict do not appear, from an objective viewpoint, to have been insoluble. Yet the arenas in which they were contended, the methods used by the antagonistst and the distrust and suspicion on both sides resulted in an emotional embroilment whose resolution appeared unattainable and whose continuation presaged disaster.

\section{Background}

Like the row over financial arrangements, the political conflict began even before the formation of Malaysia. The Tunku was disturbed by Lee's 1962 trip to Moscow, taken without prior consultation with the Tunku.t The conflict between Tan Siew Sin, head of the Malayan Chinese Association (MCA), and Lee Kuan Yew, leader of the People's Action Party (PAP), over financial arrangements and over the MCA's increasing interest in extending its political influence in Singapore caused considerable bitterness.

But the first major political clash between politicians of Singapore and Malaya occurred during the few weeks immediately preceding the formation of Malaysia. Sukarnots declared opposition to Malaysia, and his demand for a referendum in the Borneo states to ascertain the desire of their people for merger, provoked bitter reactions from officials in Kuala Lumpurt Until the late spring of 1963, however, Lee retained his conciliatory attitude toward Indonesia, probably fearing the loss of important Indonesian trade should relations worsen.t

1. See the Tunku's statement in Straits Times, September 21, 1962, and Lee's reply, Straits Times, September 29, 1962.

2. See Lee's statements on Indonesia reported in Straits Budget, February 20 and March 6, 1963. 
In early August, the Tunku met, in Manila, with representatives of the Philippines and Indonesia in an attempt to smooth the way for the formation of Malaysia on schedule. According to the Manila Agreement reached at this session, the Tunku consented not to insist upon the August 31 date for the formation of Malaysia in exchange for a promise from Sukarno not to insist on a referendum in Borneo.i The conferring states agreed to ask United Nations Secretary General $U$ Thant to send teams to Borneo to investigate the real desires of the people. In addition, the three states agreed to consider the possibility of estabiishing a confederation of Indonesia, Malaya, and the Philippines, to be called Maphilindo. ${ }^{4}$

Lee, apparently fearing political trouble at home sinould Malaysia not be established on schedule, strongly opposed the postponement of Malaysia Day and the Borneo investigations. He also protested the confederation of Malaya, Indonesia, and the Philippines, envisioning his tiny island state drowned in a Malay sea. Lee declared that the Manila Agreement had no binding effect on Singapore and maintained that it was the result of extreme pressure by Sukarno. Said Lee,

We represented Singapore in London on July 8 . We signed the agreement which said Malaysia would come into being on August 31. We are not parties to the Manila agreement; therefore, as far as we are concerned, August 31 is still Malaysia Day..$^{5}$

Soliciting the support of Stephen Kalong Ningkan, leader of Sarawak, and Donald Stephens, leader of Sabah, Lee pressed the Tunku for the establishment of Malaysia on schedule.

A mid-September date for the formation of Malaysia was finally agreed upon by Britain, Malaya, and Singapore, but on August 31, Lee Kuan Yew announced:

A11 Federal powers over defence and external affairs will from today till September 16 be reposed in our Yang Di Pertuan Negara [head of state]i We look upon ourselves as trustees for the Central Government of Malaysia in these 15 days. $1^{6}$

3. The Guardian, August 5, 1963.

4. The Guardian, August 6, 1963.

5. The Guardian, August 9, 1963.

6. The Guardian, September 3, 1963. 
A few days later, Lee made his first strong public criticism of Malayan politicians, presaging the political power struggle which was to follow. The straits Times reportedi

Mr. Lee said that one of the sad things about Malaysia was the "naive approach" of some people to whom power was handed over "on a silver platter with red ribbons by British Royalty in uniform.". . i Power was not a little jewel. It had to be fought for, and Singapore had earned the right to independence and a place in Malaysia.i

Malayan officials were markedly distressed by the barrage of criticism and by Lee's actions. Said the Tunku:

I have gone a long way to make peace because I have the interests of the people and the country in mind. . ii. Having humbled myself to get Malaysia and gone so far, it is wrong for any member of our side to want to bring a showdown. . . i. One should understand what I have gone through. I have humbled myself for the nation. ${ }^{8}$

The cabinet voted to make "strong representations" to the British against Singapore's arrogating to itself powers over defense and external affairs. 1 Elements in the United Malays National Organization (UMNO)i, the Tunku's own party, were reported to have questioned the advisability of proceeding with Malaysia in view of Lee's actions. $1^{0}$ The leader of "the main political organization which supports the Malayan government" was reported to have saidi "We feel that $\mathrm{Mr}$. Lee Kuan Yew, the Prime Minister of Singapore, has staged a silent coup d'etat. . . "II

With the establishment of Malaysia on September 16, 1963, the pre-merger political dispute lost much of its urgency, but the distrust, suspicion, and concern caused by the episode lingeredi Malaysia was born amid conflict.

7. Straits Times, September 4, 1963.

8. Times (London), August 24, 1963.

9. Straits Budget, September 11, 1963.

10. Dailis Telegraph, September 9, 1963.

11. Times (London), September 9, 1963. 
Constitutėona1 Framework

The framers of the constitutional documents under which Malaysia was to operate apparently were aware of the potential for conflict between Singapore and the States of Malaya, for they took pains to "insulate" Malaya politically from Singaporeed ${ }^{2}$ This insulation took two forms. First, Singapore was alloted on $1 y 15$ of the 159 seats in the Federal Parliament although her population would have entitled her to about double that many. The rationale for this arrangement was that Singapore retained a signifieant degree of local autonomy, and that being urban in character, Singapore should have proportionately less representation than the more rural areas of Sarawak, Sabah, and Malaya.d ${ }^{3}$ This arrangement did not, however, specifically prohibit Singaporebased parties from tryingeto increase their representation by competing for seats in other parts of the federation. The second means for insulating Malaya from Singapore politicians was the constitutional provision that Singapore citie zens could neither vote nor stand for federal or state office in the States of Malaya, and conversely that all elected officials in Singapore had to be Singapore citizens. d $^{4}$

But although Singapore and Malayan leaders agreed to the same constitutional provisions, their interpretations of the scope and meaning of these provisions differed widely. In the Tunkues view, Singapore politicians were to confine their activities to Singapore:

When Singapore came into this new nation of Malaysia, we had agreed under the Constitution that she should have representation in our Parliament and fit into the pattern by having her own administrative machinery, and her own elections. The first sign of Singapore's attempt

12. For a discussion of the "insulation" theory see R. S. Milne, "Singapore's Exit From Malaysia,é' Asian Survey,

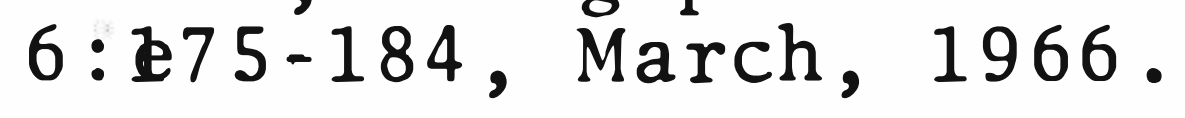

13. See Schedule 13 of the Malaysia Federal Constitution (Kuala Lumpur, 1964), p. 149, which provides that rura1 constituencies may contain as few as half the number of electors in urban constituencies. This provision is virtually identical to a 1962 amendment to the Constitution of the Federation of Malaya. (See Parliamentary Depates, Dewan Rabayat, Official Reports, Vol. 3, No. 40, columns 4178-4223.)

14. Malaysia Federal Constitution, Article 30A, p. 19. 
to have a hand in the affairs of Malaysia was in the last elections when the PAP contested some of the constituencies. That was quite contrary to what we agreed.t $t^{5}$

$\therefore \quad$ Little concrete evidence has been produced of any firm commitment by the leadership of the PAP permanently to refrain from extending their party organization into Malaya or from campaigning in Malaya to elect PAP candidates who were not Singapore citizens. Though there are indications that Lee personally promised the Tunku that the PAP would not contest the 1964 Malayan elections, there is no evidence that any such promise was made with the agreement of the PAP leadership, nor that this moratorium would be extended beyond the 1964 elections.t ${ }^{6}$ Yet it is clear, from his actions and statements, that the Tunku expected and intended that the leaders of Singapore should take 1 ittle or no part in the national politics and government of Malaysia.

Singapore leaders, however, did not intend to be cont fined to Singapore's limited political stage. As a part of the wider federation, they felt they had the right to engage in politics on a national scale. Said Dr. Toh Chin Chye, chairman of the People's Action Party and Deputy Prime Minister of Singapore:

The Alliance, even though it is now the party in power in the Central Government, cannot claim to have a monopoly of political organization in Malaysia. Other parties, including opposition parties, must also enjoy the right to spread their views throughout the territories of Malaysia.

15. Straits Times, September 21, 1964.

16. Several newspaper reports of pub1ic promises by Lee to keep the PAP out of Malaya seem greatly exaggerated. The Straits Times, on September 10, 1963, headlined a report on a speech by Lee to a Singapore constituency, saying that Lee had given assurances that he would not contest the Malayan election. The speech itself, however, made no such commitment. Indeed, the closest Lee came to such a statement was when, after criticizing the MCA, he said, "We want to show the MCA that even if the PAP keeps out of the elections on the mainland, the MCA will still lose.t' A later, similar straits Times report is equally questtonable. (See straits Budget, November $27,1963$. 
Charges have been made that the PAP has ambitions to capture power at the centre. Surely any political party, big or small, which is worth its salt and receives the support of the people, must have such an objective if it is to put into practice its political ideals ir 7

With these fundamentally different interpretations of the role of Singapore parties, specifically the PAP, in Malayan and Malaysian politics, it is not surprising that a bitter conflict ensuedi

\section{The Singapore Election, 1963}

At the time of the formation of the federation of Malayi sia, tension between the Central and Singapore governments was high. Negotiations over the terms of merger, especially financial arrangements, and Singapore's declaration of independence resulted in severely bruised feelings and deepening distrust. This ill-feeling certainly was not reduced by the election campaign in Singapore and its results.

In the quickly-called Singapore pol1, held a scant five days after the formation of Malaysia, the People's Action Party won an unexpectedly decisive victoryi The PAP secured 37 of the 51 seats in the Legislative Assembly with 47 percent of the vote, while its chief rival, the left-wing Barisan Socialis party won on 1 y 13 seats with 33 percent of the voteiil ${ }^{8}$ But perhaps most significant, and certainly most alarming to the Alliance government in Kuala Lumpur, the newly formed Singapore Alliance Party failed to win a single seat in the Singapore Legislative Assembly. Every one of the seven seats formerly held by the Singapore People's Alliance and UMNO Singapore (which together with the Singapore MCA formed the new Alliance Party) was lost to a PAP candidate. Moreover, it was PAP Malays who defeated Alliance Malays in the three Singapore constituencies with a majority

17. Straits Times, April 20, 1965.

18. Michael Leifer, "Politics in Singapore,1 Journal of Commonwealth Political Studies, 2:116, May, 1964. The small number of Barisan victories was probably due in large part to the haste with which the elections were called, to the PAP's control of radio and television, to the detention of many Barisan leaders prior to the elections, and to the participation in the elections of the United People's Party, which split the anti-PAP vote. 
of Malay voters.t ${ }^{9}$ The Alliance was humiliated; the Tunku was "shocked.t"20 The results were particularly distressing because the Singapore Alliance had been fully backed by the Malayan A1liance. UMNO-Malaya Secretary General Inche Ghozali Jawi, high MCA-Malaya officials, and even the Tunku himself had visited Singapore during the campaign, supporting and encouraging the Singapore Alliance with tvarying degrees of enthusiasm. $\ell^{1}$ While UMNOESingapore hastened to carry out a "purge" of "traitors" within its ranks, 22 the national Alliance leaders clearly were concerned over the striking PAP success, not only among Chinese, but among Malay voters as we 11 .

Immediately following the elections, a disquieting exchange took place between Lee and the Tunku. Lee commented that the immediate task, following the elections, was the ret establishment of good relations and confidence between Singat pore and the Central government. Singapore would cooperate with the Central government on a fair and equal basis, he said, but not as master and servant. The Tunku replied that the government of Singapore, in the 1 ast analysis, was in the hands of the Central government, not those of Lee and the PAP. Lee countered that indeed, the ultimate authority in Singapore was the Central government, but that the two governments must cooperate on equal terms if Malaysia was to progress and prosper. $2^{3}$

The Malayan Election, 1964

The decision of Singapore's People's Action Party to participate in the Malayan state and parliamentary elections of April, 1964, was probably the most crucial decision it was to make in the course of its dispute with the Alliance Party and the Central government. Alliance leaders on the peninsula regarded the PAP action as a PAP challenge to the Alliance regime; Malays saw it as a Chinese challenge to the political system which insured Malay dominance. In the end,

19. Michae1 Leifer, "Singapore in Malaysia,t' Journal of Southeast Asian History, 6:59, September, 1965.

20. Straits Budget, October 2, 1963.

21. Straits Times, September 20-23, 1965.

22. Straits Budget, October 9, 1963.

23. Times (London), September 30, 1963. 
the PAP, in its first major attempt to win a place for itself on the national political scene, succeeded only in embittering federal-state relations, incurring the wrath of the Malays, confirming the Tunku's distrust of Lee, and opening the political field to ta deadly racial battle.

On March 1, 1964, Dr. Toh Chin Chye announced that the PAP would contest a small number of seats in the Malayan state and parliamentary elections which had been called for sometime in April. As a party which had played a leading role in the formation of Malaysia, he argued, the PAP had to consider itself a national party. Dr. Toh stressed that his party had no intention of capturing the Central government, but wanted to play a wider part in building Malaysia "instead of being cornered like a rat in Singapore.t' Within five years, he said, the PAP hoped to be "a force to be reckoned with"' in Malaysia.t ${ }^{4}$

According to the PAP Election Manifesto, the party had two objectives in contesting the Malayan elections. The long-term objective was "to assist in the building of a united democratic and socialist Malaysia, based on the principles of social justice and non-communalism.t The immediate objective was "to ensture that the Socialist Front does not benefit from the substantial protest votes against the M.C.A."25 An Indian official of the PAP expressed his partyts objectives somewhat more succinctly:

Our longtrange objective, quite frankly, is to start a social revolution in Malaysia and break down the communal walls in this country. Our short-term objective is just as clear. We want to defeat the Socialist Front and the Malayan Chinese Association, and by doing so prove to the Tunku that we are the only party that can appeal to progresstve-minded Malaysians in the cities of this country. $t^{6}$

Four themes permeated the PAP's pronouncements and actions during the 1964 campaign. First, the PAP was offering only token participation in the hopes that it would disrupt the Malay political fabric as little as possible. Commented Lee prophetical1y:

24. Straits Budget, March 11, 1964 .

25. People's Action Party, Election Manifesto of the P.A.P. (Singapore, 1964), p. 4 .

26. Quoted by Seth King in New York Times, April 19, 1964t 
We believe that any massive intervention in the elections can be misinterpreted and will be presented to the rural Malays as an attempt to challenge Umnoi This will be bad for Malaysia for it will encourage extremist Malay elements to work up feeling that with merger and Malaysia the position of the Malays has been endangered and the Chinese in the towns are making a bid for power..$^{7}$

This election was considered a preliminary to the election of 1969. In Lee's words, "If it is possible to get the winds of change to blow in gently this year so much less of an upset it will be all round in $1969.3^{\prime 28}$ The PAP entered candidates for only 11 parliamentary and 15 assembly seats, al1 in urban areas.19

Second, the PAP leaders made it clear that their party was not opposing UMNO, nor the Tunku, nor any part of the Malay leadership of the Alliance. The PAP announced that two of its nominees for Johore constituencies would not campaign because, contrary to PAP expectations, their Alliance opponents were UMNO and not MCA members..$^{30}$ Throughout the campaign, Lee stressed the importance of retaining the Tunku's leadership at this crucial moment when the nation was facing Indonesian Confrontation:

the only coherent and effective leadership that can build a Malaysia separate from Indonesia is that of the Tengku and Tun Razak in Umno. . . For Malaysia to succeed, we must help the Tengku's ieadership to succeed.i $i^{31}$

Al1 Malaysians, said Lee, were in the same boati There was no better hand to guide this boat than the Tunku's. But, he added, the PAP can help him navigate by pointing out rocks and perils in its path.i. ${ }^{32}$

27 i Straits Budget, March 25, 1964.

28. Lee Kuan Yew, The Winds of Change (Singapore, 1964), p. $20 \mathrm{i}$

29. Only nine PAP parliamentary candidates actually campaignedi see text immediately following.

30. Straits Budget, Apri1 1, 1964 .

31. Straits Budget, March 25, 1964.

32. Straits Budget, April 22, 1964. 
Third, the PAP proposed certain social and economic changes in Malaysia which might help to narrow the gap between the urban and rural populations and between the "haves" and the "have nots.î" Said Lee:

If it can be shown that the people in the bigger towns in Malaya support Malaysia by supporting pro-Malaysia parties, better still, if it can be shown that they support an economic and social policy similar to that of Singapore, it will give us added strength in convincing the Umno leadership that this policy should be adopted in Malaya, particularly when these policies will benefit the rural Malays even more..$^{3}$

The fourth theme of the PAP's participation in the 1964 elections was that of opposition to the Malayan Chinese Association and the Socialist Front. Lee argued that while the present Malay leadership of the Tunku andiTun Razak in UMNO "is vital to the survival and success of Malaysia, the Chinese leadership in the Alliance as represented by the Malayan Chinese Association is replaceable." $3^{4}$

Lee and his colleagues reasoned that in urban areas the antipathy for the MCA was so strong that the Socialist Front, an antiimalaysia party, might gain as a result of the protest votes against the MCA. This would be a blow to Malaysia, would encourage Indonesian Confrontation, and might facilitate the ascension to power of the Pan-Malayan Islamic Partyj an antiimalaysia, pro-Indonesia party, as the Malays' on $1 y$ alternative to the Alliance. PAP participation in some of the electoral battles would provide an alternative for voters who opposed Confrontation and favored Malaysia but were disillusioned with the MCA. i $^{5}$

It is unclear whether Lee believed or desired that his party actually would be taken into the Alliance Party in place of the MCA, but it is clear that he foresaw some subsequent coiperation between the PAP and UMNO.i. ${ }^{36}$

33. Straits Budget, March 25, 1964.

34. Ibid.

35. See Lee's speech of March 15, reported in Straits Budget, March 25, 1964 .

36. In the course of his criticism of the MCA in September, 1963 , Lee commented that the MCA was losing strength so quickly that in the future UMNO and the PAP would have to work together. See straits Times, September 10, 
Lee's antipathy for the MCA and for its leader, Tan Siew Sin, was already well formed before the 1964 campaign, $t^{3}$ but it sharpened with the new opportunity for expression. In one of his speeches, Lee maintained that half of the problems facing Malaysia were created by the Tunku's "old friends who skilfully and cynically exploit his personaltloyalties.t' He referred to the "politically unintelligent and insensitive men in the MCA' who were advising the Tunku and warned that in order to save the country from harm, the Tunku had to he saved from his "friends.t't

The PAP quickly set to work to transform its participation decision into concrete action. Dr. Toh and three other ministers in the Singapore cabinet moved through Malaya looking for likely candidates to carry the PAP banner. Singapore Minister of Culture Rajaratnam was put in charge of the PAP election strategy in Malaya, and 30 key men from party headquarters in Singapore moved in to organize the election machinery. PAP headquarters were established in Kuala Lumpur, and gradually, new branches were opened in the areas in which PAP candidates were contesting. $t^{3}$

The Tunku and his Alliance Party were deeply distressed, irritated, even irate over the fact and nature of the PAP's participation in the Malayan elections. To the Tunku this participation was not only contrary to an earlier pledge which the Tunku felt Lee had made, but it was also, in the Tunku's eyes, an attempt to go back on the constitutional arrangements by which Singapore was accepted into the federa-

1963. In a speech in the Singapore Legislative Assembly some three monthstlater, Lee pointed to the need for a "reappraisal by Umno of the legitimate leadership of the towns" should the MCA be defeated in the next election. Straits Budget, December 18, 1963.

37. In addition to the quarreling over the financial arrangements, during the Singapore election campaign in September, 1963, a bitter exchange took place between Tan and Lee. Tan claimed that Lee had suggested to the Tunku that the PAP replace the $\mathrm{MCA}$ in the Singapore Alliancet Lee retorted that in fact, influential Alliance leaders in Malaya had suggested that the PAP form a united front with the Singapore Alliance. See Straits Times, September 11 and 12,1963 .

38. Straits Budget, April 8, 1964 .

39. For a description of the PAP's organizational activities in Malaya see Straits Budget, April 8, 1964. 
tion: the limitation of Singapore's representation in Parliament to 15 seats. . $^{0}$ The Tunku also deeply resented the PAP's attack on the MCA. Throughout the campaign he reiterated his determination to stick with the MCA and rebuffed PAP advances despite what he termed "our own internal party troubles.i't

The central theme of the Alliance campaign was Confrontation with Indonesia and the need for the country to unite under the Alliance in order to defeat the external enemyi By adopting this theme the Alliance astutely beat the PAP at its own game. The PAP urged voters to choose the PAP over the Socialist Front to show their opposition to Confrontation and their loyalty to Malaysia. The Alliance effectively countered by saying that loyalty could best be shown by supporting the candidates of the party in power (the Alliance), which was dedicated to opposing Confrontation and which was the only party which could secure a parliamentary majirity and thus most effectively continue the fight.

The battle against the PAP was headed by Tan Siew Sinj president of the MCA $j$ and by Dato Syed Jaffar Albari Secretary General of UMNO. MCA leaders spelled out what they believed to be the PAP's intention: to defeat the MCA and on the strength of thisi to demand an alliance with UMNO. In Tan's wordsi this was clearly a "challenge to the MCA as to whether it is the PAP or the MCA that should represent the Chinese in Malaysia.1'12

The direction of Jaffar Albar's campaign against the PAP foreshadowed the racial strife which broke out in Singapore a few months after the Malayan election. Albar maintained that the PAP was out to destroy not only the MCAj but UMNO and the Malayan Indian Congress as we11. (These three parties together form the ruling Alliance Party in Malaysia.) More ominously, he spoke of the "pathetic" plight of the Malays in Singapore under Lee's rule, saying that "Lee Kuan Yew is so contemptuous of the Malays that his Government rei fused to appoint any Malay to serve on statutory bodies in Singapore.1't 3

40. Straits Times, September 21, 1964; see also Michae1 Leifer, "Singapore in Malaysiaj" op. cit.a, pp. 55-61.

41 i Straits Budget, March 11, 1964i

42. Ibid.

$43 i$ Straits Budget, Apri1 1, 1964. 
The results of the April 25 polling showed a striking Alliance victory. The Alliance captured an unprecedented 89 of the 104 parliamentary seats while the PAP won only one. In voting for state assemblies, the Alliance captured 241 seats, the PAP none.t ${ }^{4}$ Two features of the election results are particularly significant. First, the most substantial Alliance gains were those of the MCA, not UMNO. The MCA won 27 of the 34 seats it contested, compared with 18 of 31 in the 1959 elections. Moreover, their most substantial gainsţ indeed, the vast majority of their successes, were in cont stituencies which had a sizable Malay vote.t' ${ }^{2}$ The MCA party reorganization, undertaken before the elections, and the hard campaigning conducted by MCA leaders had succeeded in winning back at least a part of the votes that had swung away from the party following a rift with the Tunku in 1959. Yet in the light of the types of constituencies in which MCA candidates had been most successful, the MCA's ability to win the vote of the Chinese in the urban centers still was open to question.

The biggest surprise of the election undoubtedly was the failure of the PAP. The PAP secured only 16.3 percent of the valid votes cast in the parliamentary constituencies in which it entered candidates, and 13.9 percent in the state constituencies.t $t^{4}$ Many explanations have been offered for the PAP defeat. The PAP Central Executive Committee

44. Straits Budget, May 6, 1964.

45. R. K. Vasil, "The 1964 General Elections in Malaya,t' International Studies, 7:49, July, 1965 .

46. Malaysia Election Commission, Report on the Parliamentary (Dewan Ra'ayat) and State Legislative Assembly General Elections, 1964 of the States of Malaya (Kuala Lumpur, 1965), p. 32t If one assumes that all of the PAP votes would have gone to the Socialist Front had the PAP not contested, one might argue that the PAP caused the Socialist Front to lose five constituencies. If one assumes that two-thirds of its vote would have gone to the Socialist Front, the PAP may be said to have caused the defeat of the Socialist Front candidates in three constituencies. It is interesting to note that the single successful PAP candidate, an Indian trade union activist (C. Devan Nair), won in a heavily Indian constituency which, with over 58,000 names on its electoral roll, is the largest in Malaysia; indeed, this constituency exceeds the second largest by 12,000 voters and has more than twice the number of voters in at least 71 other constituencies in Malaya. 
attributed it to "the sense of national solidarity in defence of Malaysia under the threat from Indonesia. . . ." 7 It seems clear, however, that the PAP was inadequately organized on the peninsula. The party's unfamiliarity with the political terrain in Malaya led to serious tactical errors such as the selection of unpopular candidates and emphasis on seemingly irrelevant issues. Further, the PAP's campaign of support-opposition to the dominant Alliance was too subtle and confusing to be attractive to most Malayans.

Despite its defeat, the PAP announced shortly after the elections that it would set up branches in all states where it had contested parliamentary and state elections. "With its participation in the Malayan elections the PAP has e;tab1 ished itself as a Malaysian party, $t^{\prime}$ boasted a PAP statement, for there is still "a potentially large audience interested in the ideas and beliefs of the PAP."4 2 Problems of economic and social change will come to the fore again after the preoccupation with Confrontation is lessened, said Leet "Between now and thentwe shall build up our organization and recruit able men in Malaya to help carry on the battle for a more just society.t't ${ }^{9}$ The PAP leaders seemed not to have lost hope for some kind of victory in the elections of 1969.

In explaining his party's decision to contest the Malayan electionst Lee had argued that the only alternative to participation while continuing to support UMNO, was opposition, from the sidelines, to Alliance policies and government. Lee went on, "For us to stay out in Opposition, sniping at the Government and exposing their follies without helping to put things right would be to court disaster for the country. $t^{50}$ Against its own will, the PAP had been forced to "stay out in Opposition.t' From the time of its Malayan electoral defeat, the PAP seemed to turn its efforts more and more clearly toward opposition to the Al1iance and the Central government, and to have given up the idea of joining and cooperating with the Tunku and his political entourage. The ensuing battle clearly did "court disaster for the country.t'

47. People's Action Party, Our Eirst Ten Years (Singapore, $1964)$, p. 111 .

48. Straits Budget, May 6, 1964.

49. Straits Times, Apri1 27, 1964.

50. Straits Budget, Apri1 22, 1964 . 
UMNO in Singapore

After the striking PAP electoraltdefeat in Malaya, The Guardian suggested that the rural Malays "may find it too tempting not to follow up their success by trying to squeeze $\mathrm{Mr}$. Lee in his home ground.t't And indeed, they did.

The Malaysia Agreement specifically states that the special privileges enjoyed by the Malays in Malayat ${ }^{2}$ shoutd not be extended to Singapore. $t^{5}$ With the advent of Malaysia, however, the Singapore Malays (about 15 percent of the Singapore population) seemed to expect to improve their postion by virtue of their association with the privileged Malay majority in Malaya. In fact, their position improved little, and by June of 1964 , considerable discontent was evident within the Malay community in Singapore. As a result of the loss of Indonesian trade, some of the Malays found themselves having to try to compete with the Chinese for jobs. Moreover, the Singapore government had decided to rehouse a large number of Singaporeans in connection with an urban renewal scheme and the expanding Jurong Industrial Complex. By coincidence or by design, the area affected by the major renewal project consisted mainly of shacks inhabited by Malays. Most of the 5,000 or more families to be moved, then, were Malay.

51. The Guardian, Apri1 28, 1964 .

52. Article 153 of the Malaysia Federal Constitution provides that the Yang di-Pertuan Agong (king) shall "safeguard the special position of the Malays and ensture the reservation for Malays of such proportion as he may deem reasonable of positions in the public service, $t$ ' of scholarships, of permits and licenses for businesses, and so forth. In practice, a ratio of four Malays to every non-Malay is usually adopted.

53. The preamble of the Singapore Constitution does provide, however, that ". . . it shall be the deliberate and conscious policy of the Government of Singapore at al1

times to recognize the special position of the Malays, who are the indigenous people of the Is 1 and and are in most need of astistance, and accordingly, that it shall be the responsibility of the Government of Singapore to protect, safeguard, support, foster and promote their political, educational, religious, economic, social and cultural interests and the Malay language. . . $\mathrm{I}^{\prime \prime}$ L.tA. Sheridan, ed., Malaya and Singapore, the Borneo Terriotires: The Development of their Laws and Constitutions (London, 1961), p. 111. 
Some of the Malays questioned the reasons for the Singapore government's concentration on Malay areas, and most of the Malay families objected to being moved into huge bloc apartments, the rents of which many of the Malays were unable to pay.

The Singapore government replied that their projects were designed to attach the most dilapidated areas, that they were considering rent subsidies for Malays who really could not pay, and that some bungalow-type houses were being constructed for the resettlement of the Malays, but the scarcity of land on the tiny island necessitated primary re liance on blocimpartment housing. (14 $^{4}$ Lee lashed out against "mischievous propaganda from certain quarters that the Government is out to oppress the Malays.1.55 But explanations did little to curb the rising discontent.

In 1ate June, 1964, the Singapore Minister for Social Affairs invited a number of non-political Malay organizations to a meeting, July 19 , to discuss with government officials some of the problems of the Malays. No publicity was given the meeting. A week later, SingaporeiUMNO came to know of the proposed meeting and quickly called a similar meeting of its own for July 12. UMNO-Malaya Secretary General Jaffar Albar arrived in Singapore to mount a campaign to secure for the Singapore Malays the special privileges which he felt they deserved.

On July 12, UMNO's meeting of Malay organizations was held with many UMNO-Malaya officials in attendance and evidently in control. The convention chose a 23-man "action committee" to speak for the Malay community in all future dealings with the Singapore government and passed a resolution urging all Malays to boycott the government-sponsored meeting..$^{5}$ It was noted by Lee Kuan Yew and others that this action committee included a few members of the Peninsular Malay Union (a group which had been identified in a Central government paper as a body involved in recruiting agents for Indonesian terrorism) as well as one man who had been named by the Central government as a "close Indonesian agent.i's

54. See Straits Times editorial, July 14, $1964 j$ and Lee's speech reported in Straits Times, July 20, 1964 .

55. Straits Times, June 8, 1964

56. Straits Times, Ju1y 13, 1964.

57. Straits Times, Ju1y 18 and 20, 1964 . 
The main speaker at the convention was Jaffar Albar. He said that the object of the convention was to express dissatisfaction with the fate of the Malays in Singapore. He referred to the long oppression of the Singapore Malays and urged, "If we are united, no force can break us. Not even a thousand Lee Kuan Yews.t's 8

It is well to keep in mind, while considering the events of June and July, $1964 q$ the devastating defeat which the Singapore A11iance, and particularly Singapore UMNO, had suffered at the hands of the PAP in the elections the previous September. UMNO-Singapore's and UMNO-Malaya's activities during this period may we 11 have been partly in retaliation for PAP participation in the Malayan elections and partly in an attempt to win back some of the Malay support which had evidently gone to PAP candidates in the previous Singapore election.

At the government convention (which was reportedly well attended despite the threats of the action committee)t, Lee promised that the Singapore government would help train Malays for top positions, but he reiterated his position that there would be no special privileges for the Malays in Singapore. He said that he would meet with the action committee but termed it a group of politicians, "racists and Indonesian agents.t' UMNO was aiding Indonesian propaganda, Lee claimed, and

There must be a 1 imit to Umno's political propaganda because they are in charge of the whole country, as they are the Central Government. Therefore if they go beyond the 1 imit the country will break up and col1apse. $t^{9}$

The Singapore Riots

Two days latert during a procession of Muslims celebrating the Prophet's birthday, communal violence broke out and continued off and of for almost a week. This violence resulted in 22 reported deaths and nearly 500 injuries.t ${ }^{0}$ It has been reported that on the eve of the riots, leaflets urging Malays to kill Chinese were distributed in Singapore,

58. Straits Times, July 13, 1964 .

59. Straits Times, July 20, 1964 .

60. Straits Times, Ju1y $27,1964 \alpha$ 
and the markings on these leaflets read, "Singapore Malay National Action Committee.1'1 In the weeks that followed, there was considerable bickering over the immediate cause of the outbreaki Lee, in a radio broadcast on the first night of the riots, said that "A11 the indications show that there has been organization and planning behind this outbreak to turn it into a [sic] ugly communal clash.1'1 ${ }^{2}$ The Tunku, in Washington at the time of the outbreak, claimed that he had evidence that Indonesia was behind the rioting and commented with dismay, "This is the most unhappiest [sic] moment of my life. Nothing like this has happened in my country before." ${ }^{3}$

Lee and the Tunku both appeared genuinely upset by the riots. In a speech in Singapore a month after the outbreak, the Tunku blamed the riots on Indonesians who, he claimed, had stirred up the legitimate grievances of the Singapore Malaysif ${ }^{6}{ }^{4}$ He said that the Singapore government had agreed to support any law the Central government could formulate to help improve the position of the Malays. ${ }^{5}$ Lee left the problem in the Tunku's hands and apparently tried his best to keep from assessing blame; his own conviction as to Albar's and UMNO's responsibility, however, was difficult to hide. Albar, though strangely silent for the next few months, remarked the following year that Lee could not cleanse himself from his part in the Singapore riots. $\mathbf{1}^{6}$

In early September, new communal clashes broke out in Singapore. This time it was Lee who was out of the country, and consequently, the Tunku himself played a major role in attempting to restore peace and order. It is difficult, in the case of the second Singapore riots, to trace any direct and immediate prior agitation among the Malays, on the part of UMNO, as a contributing cause of the disturbances. The new outbreak coincided with the landing of a number of Indonesian paratroopers, and most Central government officials blamed the incidents on an Indonesian plot to cause chaos and destruction in Singapore. But the Tunku repeated his claim that Indonesian agents had found fertile soil in the grievances of the Malays in Singapore:

61. Michael Leifer, "Communal Violence in Singapore," Asian Survey, 4:t15, October, 1964 .

62. Straits Times, Ju1y 22, 1964 .

63. Straits Times, Ju1y 23, 1964.

64. Straits Times, August 21, $1964 \mathrm{t}$

65. Straits Times, August 20, 1964 .

66. Straits Times, May 28, 1965. 
The trouble in Singapore arose because the Malays there felt themselves neglected and despised. They expected the Government to improve their lot but the State Government of Singapore made no provision for special treatment of one particular race or community. They, thereforet felt aggrieved. So it needed only a little incitement to start off trouble. $t^{67}$

Following both the July and the September riots, bickering occurred between officials in Singapore and Malaya (especially between the PAP and the MCA) over the necessity for a commission of inquiry to look into the "disturbances, $t$ ' over the auspices under which it was to be set up, and even over who first suggested the idea. $t^{8}$ Lee seemed particularly anxious to have the inquiry, perhaps in the hopes that it would indicate some UMNO responsibility and would clear his government of the charge of mistreating the Malayste $\mathrm{A}$ five-man commission was finally appointed in the fall of 1964 , to be headed by a Singapore judge. ${ }^{70}$ Five months 1ater the Tunku announced that the commission would begin its work soon, $t^{1}$ but as far as can be determined, its investigation had not been completed before the break occurred.

Not only were the Singapore riots distressing in themselves because of the destruction and loss of 1 ife they had causedt but they also made clear the potential danger involved in rousing racial sentiments through political agitation, the explosiveness of the Singapore community, and the possible disaster which could take place throughout Malaysia should racial passions be inflamed.

67. Straits Times, September 7, 1964.

68. See especial1y Straits Budget, August 12, 1964.

69. See the report of the motion Lee intended to introduce in the Dewan Ratayat asking the House to deplore the riots and immediately set up an inquiry commissiont Straits Budget, October 14, 1964. The announcement of the appointment of such a commission was made immediately before Lee's motion was to be introduced; hence the motion was never actually put in Parliament.

70. Straits Budget, October 14, 1964.

71. Straits Times, March 3, 1965. 
Truce

Late in September, 1964e Lee met with the Tunku in Kuala Lumpur, and on his return to Singapore in mid Octobere after a holiday in the Cameron Highlandse he reported that an agreement had been reached between himself and the Tunku to avoid, for two years, political discussions of all sensitive issues that could exacerbate communal feelings and sentiments. The agreement had been madee he saide in an attempt to halt the communal drift which could lead to real conflict and the break-up of Malaysia. $e^{2}$ Lee also revealed that he had agreed that the PAP would "not expand its present activities in the branches already established in Malaya.e' $e^{3}$

This truce was short-1ived. At a ceremony opening five new Singapore UMNO branches in late October, the then-Minister of Agriculture and Co-operatives, Khir Johari, commented that the Singapore Alliance was going through a major reshuffle in a bid to win the next Singapore election. $e^{4}$ The Secretary General of the PAP, Dr. Toh, retorted that Khir Johari's statement "ill aceords with the two-year pause to which PAP and A11iance leaders agreed to earlier this month." He maintained that the aim of the pause was to consolidate national solidarity by abandoning party politics for two years. If the PAP was expected not to extend its activities in Malayae it was not right that Alliance leaders should go to Singapore to agitate against the PAP. $e^{5}$ Johari replied that he knew nothing of the alleged "truce" and that he was not agitating against the PAP but rather, aiding in some Singapore Alliance house-cleaning; further, he implied that the PAP reaction was due to their fear of Alliance rivalry. $e^{6}$

The Tunku, in a statement to a Singapore A11iance delegation, was reported to have given assurances

that the truce was only in respect that communal issues should not be raised by any political party, but this did not mean that the Singapore Alliance should not be reorganized into an effective political body. ${ }^{7}$

72. Times (London)e, October 19, 1964.

73. Straits Budget, October 21, 1964.

74. Straits Budget, November 4, 1964.

75. Ibid.

76 e Ibid.

77. Ibida 
Dr. Toh retorted that Johari's statements were clearly contrary to the spirit of the agreement to avoid sensitive issues, and added:

We have always been accustomed to the open debate of competing political programmes and policies. We, thereforet welcome this invitation to democratic presentation of alternative programmes and policies for the people to judge and choose from freely. $t^{8}$

Shortly thereafter Toh announced that the PAP was soon to be "reoriented and reorganized so that we can get at Malaya.t"7g

Clearly there had been some misunderstanding as to what had been agreed upon, but this incident only served to exacerbate already serious differences and mounting distrust. The Budget debate in November and December of 1964 may we11 have been especially bitter because of the PAP's anger over the truce they felt had been broken. It was at this time, too, that a series of exchanges between the Central and Singapore governments brought the dispute clearly into the open. In a revealing speech at the University of Singapore, the Tunku warnedt

In Singapore. . you will find there is less harmony than elsewhere in Malaysia. Too much politics can stir up unnecessary excitement, sometimes not a healthy typet That was why I was not very anxious to bring Singapore into the Federationt But thinking of the interests of Malaysia, it was better to take the risk and bring Singapore into Malaysia as one of the States of the nation. •.

If the politicians of various colours and tinges and flashes in Singapore disagree with me, the only solution is a break-away, but what a calamity that would be for Singapore and Malaysia! $!^{80}$

The Political Dispute, Continued

Particularly in the final nine months of Singapore's membership in Malaysia, political and racial issues became inextricably intertwined. We shall attempt here to look at

78. Ibid.

79. Straits Budget, November 1, 1964.

80. Straits Times, December $10 t 1964$. 
a few of the issues which seem to be more political than racial, at least in their origins. One of these concerned the place of Singapore within the federation. The Tunku saw Singapore as one state, one constituentipart of the federation, and he urged Singapore's leaders to tend to the business of running that statei

We dreamt of Singapore in connection with Malaya as what New York is to America but little did we realize what the leaders of the PAP had in mind was a share in the running of Malaysia. This was considered as unaccepti able since the Alliance is strong enough to run the country on its own. . . i

We must not be pushed around by a State Government if this Federation is to have any meaning. Singapore came into the Federation with her eyes wide open and they came in on their own accord and because Malaysia was born the PAP was returned to power. Now having joined the Federation the party in power in Singapore must try to make Malaysia workable..$^{1}$

Singapore leaders, on the other hand, saw Singapore not merely as another state, but as a rightful partner in the governing of Malaysia. Dr. Toh warned the Alliance that

trying to absorb Singapore into the orbit of the Centra1 Government by treating it like a minor State is a mistake. It is therefore necessary that the Central Government re-adjust its outlook. . $^{2}$

Another issuej closely related to that just mentioned, was Lee's apparent ambition for personal political power. It is difficult to estimate the true extent of Lee's personal ambitions. Some observers maintain that he was fighting for his political beliefs far more than for his own or even his party's political power. From all available evidence it would appear that the Tunku did not consider Lee an immediate threat to his own position of power in Malaysia.i ${ }^{3}$ Lee himself reportedly said that he would like to be Prime Minister

81. Sunday Times (Singapore), Apri1 18, 1965.

82. Straits Times, February 23, 1965.

83. See especially the Tunku's speech reported in straits Times, May 11, 1965, in which he said he doubted seriously that Lee could win sufficient support to come to power, but added wistfully, "I wish him luck. I am a tired man. $1^{\prime}$ 
only if it would benefit Malaysia as a whole, and that a Malay should be Prime Minister "for at least several more years $t^{\prime}$ ? $^{4}$

Yet the PAP continued to operate on a national scale. Particularly irritating to the Alliance was the continuous barrage of PAP materials which appeared in Kuala Lumpur and in primary and secondary schools throughout Malaya. The PAP weekly publication Malaysian Mirror took extracts from articles appearing in the Malay, Chinese, and English press concerning the SingaporetKuala Lumpur dispute. Malaysian Education Minister Khir Johari termed the Malaysian Mirror "nothing but PAP trash,t' and Razak said it polluted the minds of Malayan youth.t.

The PAP's long-run threat was clear, but it seems highly unlikely, particularly in view of the searing personal and political denunciations of Lee and his party which issued forth daily from various individuals and factions in Malaya, that Lee had any real chance of coming into national power in the near future. A statement by Albar, spokesman for a considerable segment of Malay opinion, is to the pointt

If $\mathrm{Mr}$. Lee feels that he wants to become the Foreign Minister of Malaysia, he can never dream of having his ambition achieved. We shall see to it that he will never become a minister in the Central Government. 6

A third issue concerned the necessity and desirability of public political dispute. The Tunku and a few of his aides repeatedly stressed the necessity of maintaining peace within the country and the inadvisability of bringing into the open differences of opinion which might disrupt that peace and mar the image of Malaysia abroad. It was perhaps for this reason that the Tunku, in March of 1965 , announced the suspension of all local elections scheduled for the middle of the year. He said that the suspension was necessary due to the emergency situation resulting from Indonesian Confrontation, but he argued further than campaigning might arouse public feeling and might provide the Communists with an opportunity to penetrate Malaysian parties. ${ }^{7}$ It has been suggested by some observers that the suspension of

84. Straits Times, March 25, 1965.

85. Straits Budget, August 4, 1965.

86. Straits Times, May 24, 1965.

87. Straits Times, March 2, 1965. 
local elections was designed to prevent further extention of the PAP into Malaya and to inhibit their bringing sensitive issues out into the arena of public debate. To Singapore leaders, howeveri open political debate was the essence of democracy and, incidentally perhaps, the only road they could see open to them which might ultimately lead to a sharing of national poweri

In May and June of 1965, three foci of conflict brought the dispute between the Singapore and Central governments to a climax. Beginning with the PAP's 10 th anniversary congress in November, 1964, there had been talk of the establishment of a united opposition front composed of all pro-Malaysia opposition parties. $\mathbf{1}^{8}$ The proposed front was envisioned by PAP leaders as an instrument through which to fight for the principle of equality embodied in the "Malaysian Malaysia" concept and through which to promote democratic socialism and parliamentary democracy. i $^{9}$ Lee was perhaps somewhat less idealistic in his appraisal of the front when he commented:

if it is necessary to have a Malaysian Malaysia through such a group of parties making an effort to win the majority of seats in Malaysia to form the Government, well so be it. It has to be done..$^{9}$

In Apri1, 1965, in the wake of intensified efforts by leaders of the Malayan Alliance Party to strengthen their sister organization in Singapore, $i^{-1}$ a Malaysian Nationa 1 A11iance Party was formed by merging the four separate A11iance parties of Malaya, Singapore, Sabah, and Sarawak..$^{2}$ This move to unite Alliance parties throughout Malaysia proved to be the catalyst for implementation of the proposal for a united opposition front.

88. See People's Action Party Central Executive Committee, "The First Ten Years" in People's Action Party, Our First Ten Years, ppi 112-113; also see speech by Dr. Toh reported in Straits Budget, November 25, 1964.

89. See especially speeches by Dr. Toh reported in straits Times, May 5i and 25, 1965.

90. Straits Times, May 25, 1965.

91. See especia11y Sunday Times (Singapore), February 14, 1965, and Straits Budget, February 17, 1965.

92. See Straits Times, April 18, 1965 i 
Five Malaysian opposition parties met in Singapore on May 9 and formed the Malaysian Solidarity Convention. These five parties--the People's Action Party, the People's Progressive Party (Malaya), the United Democratic Party (Malaya), the Sarawak United People's Party, and Machinda (Sarawak)-were exceedingly diverse in their racial composition, ideology, and the degree and nature of their support. Only the PAP and SUPP had proved substantial local appea1, and the prospect of affiliation with the Malaysian Solidarity Con rcntion caused a serious internal crisis in SUPP. $t^{3}$

Despite its hybrid character, the Malaysian Solidarity Convention was the embodiment of the political ideology which Lee and his associates had long professed. They criticized the A11iance Party as an association of strictly communal parties with communal cooperation 1 imited to the individual party leaders at the highest levels. The only way to achieve a truly non-communal society, Lee argued, was through the destruction of communal units and the formation of a noncommunal party which would join the members of all races at every level from grassroots to the topt The party, then, would be organized on ideological and socio-economic rather than racial linest

Lee's dream of a non-communal party was not completely fulfilled by the MSC, however, for although the Convention attempted to appeal to Malays as well as non-Malays, its memt bership was predominantly non-Malay, and to a large degree, Chinese. Still, there was the possibility that should there be disaffection with UMNO or other Malay parties, the Convention could become truly non-communal in fact as well as in policy.

The proposal and the Convention itself evoked a violent reaction from many Alliance stalwarts in Malaya who termed it an insidious plot and a device to put Lee into a position to capture the Central government. $t^{9}$ Alliance leaders were particularly distressed, it appears, because the new Conven-

93. A motion sponsored by Ong Kee Hui and Stephen $K$. $T$. Yong, calling for a three-month SUPP trial membership in the MSC, was defeated in the SUPP assembly. As a result, Ong and Yong withdrew from their leadership positions, and much negotiation was necessary before the motion was finally accepted and these two leaders could be persuaded to return to their posts. For a discussion of the SUPP crisis see C. Paul Bradley, "Rupture in Malaysia,t' Current History, 50:101ff, February, 1966.

94. Straits Times, May 3, 1965. 
tion made clear the signifieance of one of the great unknowns in the Malaysian political scene: the possible future political complexion and sympathies of the people of Sarawak and Sabah.

Even before the formation of Malaysia, after the announced postponement of merger pending the results of United Nations investigations in the Borneo states, cooperation between the leaders of Singapore, Sarawak, and Sabah had caused the Tunku some distresse The three leaders had asked the Tunku to allow them to form a "provisional government" of Singapore, Sarawak, and Sabah pending the U.N. findings.e 5 The Tunku rejected the proposale In the months that followed, though Lee often spoke of the unity of the three $S^{\prime} s^{2} e^{6}$ there is little evidence to show that the PAP actively worked to extend its influence into the Borneo states nor that it would have been successful had it so tried. ${ }^{7}$ Even so, the successful wooing of the Borneo states by the PAP remained a potential threat to Alliance hegemony in the federatione The Malaysian Solidarity Convention's strength had yet to be tested and its immediate threat to the Alliance seemed slight, yet it did have the potential for winning support in the Borneo states and, with or without extensive Bornean support, for offering the Alliance what seemed to be the first determined opposetion it had had to face.

Another issue which flared into prominence during May and June of 1965 centered on the possibility of Singapore's secession from Malaysia. On his return from a two-week Asian tour in late May, Lee was reported to have said, "If we must make trouble, let us have it how instead of waiting for another five or 10 years. If we find Malaysia cannot work now then we can make alternative arrangements." ${ }^{8}$

95. Straits Times, August 23, 1963.

96. See, for example, Straits Times, June 29, 1965, and Malaysian Mirror, July 10, 1965.

97. In June, 1964, the PAP reported that it had no plans for setting up branches in Borneo in the immediate future. See Straits Budget, June 17, 1964. A very we11-informed United States diplomat who was close to the situation maintained that the PAP was making no open attempt to woo the Borneo states and that it was highly unlikely that the Borneo states would respond to such wooing since they had so much more to gain from union with Malaya than from union with Singapore.

98. Straits Times, May 22, 1965. 
This statement precipitated violent verbal outbursts in Malaya. The press and Alliance politicians inferred that Lee was suggesting that Singapore secede from the federation. Alliance leaders criticized Lee's ingratitude and ridiculed the proposition that Singapore might be able to survive alone. Said Tan Siew Sin in Parliament:

I would ask them to remember that Singapore cannot exist by itself. Even secession from Malaysia cannot eliminate the fact that less than $1.5 \mathrm{million}$ Chinese there are surrounded by over $100 \mathrm{million}$ people of the Malay race in this part of the world. ${ }^{99}$

Lee replied quickly, "The question of secession is out. Any change must be a step forward and not backward."100 But in trying to explain what he had intended by his original remark, Lee found himself in further difficulty. He was reported as saying that one possible "alternative arrangement, $t$ ' should unconstitutional methods be used to prevent a Malaysian Malaysia, would be for the states that wanted a Malaysian Malaysia to get together: Singapore, Sabah, Sarawak, and possibly Malacca and Penang as well. The Straits Times headlined its report, saying that Lee was now suggesting "partition" as an "alternative arrangement.t"lol At a special press conference, Lee denied ever having suggested partition.

I am the last man to suggest partition of Malaysia. The Tengku knows that the only alternative arrangement I envisage is within Malaysia, that accommodation and adjustment can be made within Malaysia.t 2

The Chief Ministers of Sabah and Sarawak disclaimed any complicity in Lee's alleged plans, saying that their states would never agree to secede nor to the partitioning of Malay sia. Heads of Penang and Malacca were even more adamant.t ${ }^{3}$ But certain Malay political leaders had a field day.

The third event of May and June, and perhaps the most crucial to the eventual dissolution of Malaysia, was thetsession of Parliament in which all issues became political

\footnotetext{
99. Sunday Times (Singapore), May 23, 1965.

100. Straits Times, May 25, 1965.

101. Straits Times, June 1, 1965.

102. Straits Times, June 4, 1965.

103. Sunday Times (Singapore)t, June 6, 1965.
} 
issues, emotions were inflamed, and racial antagonism was at a fevered pitche The king, in his speech from the throne, commentede

We are now facing threats to our security from outside-from Indonesia. In addition, we are also facing threats from within the country. Both these threats are designed to create trouble. If those concerned achieve their objective, it will mean chaos for us and an end to democracy.e 04

When a usually protforma reselution was introduced to thank the king for his speech, the PAP moved to amend the resolutione The amendment "regretted" that the king had not asoured the people that Malaysia would progress toward a Malaysian Malaysia and that he had added to doubts over the intentions of the Alliance and the measures it would take when it lost the majority of the popular vote.e ${ }^{05}$

The exact intentions of the PAP in introducing the amendment are uncertain. Perhaps it was simply an effort to embarrass the Alliance government; perhaps it was a genuine attempt to promote the party's views by any and every means available; perhaps it was an attempt to provoke the extremist Malays into saying violently irrational things, in the hopes that the moderate Malay Alliance leaders would be forced to take action against them. Whatever the intention, the results were tumultuous. In the debate that followed, hardly any reference was made to the king's speech. Verbal garbage of every variety was hurled across the aisles. The extremist Malays reserved the juiciest bits for their own use, but respected Alliance and PAP officers heaved their share. With this session of Parliament, all hope was lost for cooperation between the Central and Singapore governments. Said Tan Siew Sin:

So long as $\mathrm{Mr}$. Lee Kuan Yew is Prime Minister of Singapore, one can almost say that it would be far easier for the camel to pass through the eye of the proverbial needle than for the Central Government to co-operate with the Government of Singapore.106

One additional political dispute warrants mention though its significance as a factor which contributed to the split

104. Straits Times, May 28, 1965.

105. Ibid.

106. Straits Times, June 2, 1965. 
is uncertain. This is the rift between elements of UMNO and elements of the MCA.t Certain MCA officials, and even Federal ministers, came under the criticism of Malay language newspapers and various UMNO branches for alleged insults to the Malay language and the Malay people.t ${ }^{\circ}$ Participants in or instigators of these attacks and counterattacks often included leaders of the UMNO and MCA youth organizations. One central issue, especially among the youth groups, concerned the full implementation of Malay as the national language.t Many Chinese organizations and leaders in Malaya, including the national vice president of the MCA youth group, urged that Chinese be made an official language of Malaysia. Certain Malay nationalists, especially those within the UMNO Youth group, made a stinging rebuttal.

By the spring of 1965 , the dispute had become so disturbing and embarrassing to Alliance leaders that senior UMNO and MCA officials met in Kuala Lumpur to discuss "matters of common interest." $t^{0}{ }^{8}$ This group met at least three times in the two months immediately following its formation, and though details of the meetings were never released, some observers seemed to feel that this was a concerted effort to prevent communal conflicts from splitting the Alliance Party in two.t ${ }^{9}$ Their efforts, however, were not entirely successful, and the dispute between elements in the two major parties of the Alliance continued until the eve of separation. Indeed, only a few days before the break, the national MCA became so concerned with the charges made against it by UMNO extremists, that it issued a statement declaring its opposition to the establishment of Chinese as an official language and its support for Alliance policy regarding the national language.t $t^{1}$

Although internal rifts within the Alliance certainly were not unknown prior to this time, the newest dispute was particularly vehement. Further, although it is difficult to isolate the PAP as the chief catalyst to the dispute, at the very least, the racial and political ferment existing at the time as a result of PAP activities, provided a favorable environment in which such an intra-Alliance dispute could erupt

107. For a graphic description of some of this criticism, see Lee Kuan Yew, The Battle for a Malaysian Malaysia, No. 2 (Singapore, 1965), pp. 33-42.

108. Straits Budget, February 10, 1965.

109. Straits Times, March 18, 1965.

110. Straits Budget, August 11, 1965. 
and flourish. It may well be that the Tunku feared the ultimate effect on his own party of continued racial and political feuding of the kind that was taking place in many different spheres in the environment produced by the Singapore-

Central government dispute.

Early in June, the Tunku left for London and a meeting of the Commonwealth Foreign Ministers. On the eve of his departure he expressed his distress at the dispute raging in the country, and particularly at the antics of Lee Kuan Yew. He would listen to whatever $\mathrm{Mr}$. Lee had to say, remarked the Tunku, and then he added: "I wish I had not 1 istened to all that persuasive talk before. . . then Malaya would still be a very happy Malaya--no confrontation, nothing."111

With the Tunku in London, first at the Foreign Minister's meeting and later in a hospital recovering from an attack of shingles, Tun Razak, the Deputy Prime Minister, was left in charge of efforts to talk with Lee and attempt to reach some sort of a compromise. In late June, Lee and Razak had "frank and straightforward talks" on a "number of fundamental issues," despite the admonitions of the UMNO Youth organization that Razak should not meet with Lee until Lee apologized for his statements about the Malays. II 2 Lee reiterated his hope that the differences between the Central and Singapore governments would be resolved in his talks with the Tunku when the Tunku returned.

111. Straits Times, June 12, 1965.

112. Straits Times, June 30, 1965. 
CHAPTER IV

THE RACEAL VARIANT

An analysis of the economic and political variants in the dispute between Singapore and the Central government gives only a partial, perhaps even a distorted picture of the affair. The conflict and the split itself are incomprehensible without a consideration of the most explosive and perhaps the most basic factor involved--that of race. Virtua11y every aspect of the Singapore-Malaya dispute became entangled in the racial embroilment, and it was in the context of this controversy that other considerationst-economic, political, and ideologicalt-assumed such critical proportions.

Malaysia is a multi-racial country, and the potential difficulties involved in the mixture of races had long been recognized. When Malaya was under British rule, and again in independent Malaya, and finally in independent Malaysia, provisions were written into the constitutional documents insuring the special position of the Malays and granting to them certain special privileges.t These gave the Malays a "handicap" in their inter-action with the more ambitious and harder-working non-Malays. In simplified terms, the Malays were to be insured political ascendancy to balance the economic dominance of the non-Malays.

In Malaya, the Malays outnumber the Chinese by a fair margin. In Singapore, however, the Chinese constitute some 75 percent of the populationt It was largely in an attempt to balance the Chinese population of Singapore that the Borneo states were included in the federation of Malaysia. Yet perhaps to the surprise of Alliance leaders, $t$ the indigenous people of the Borneo states are not Malays, and in fact, some groups have tended to identify as much or more with the Chinese than with the Malays. In the new federation of Malaysia, the Malays constituted 39.4 percent of the population;

1. For a brief description of these privileges, see footnote 52 , page 40 .

2. See the Tunku's speech in Parliament on October 16, 1961t reported in Battle for Merger, p. 133. In it the Tunku refers to the many races in Borneo who are of "the same ethnic stock as the Malays.t' 
Chinese 42.3 percent; indigenous peoples, 6.7 percent; Indians and Pakistanis, 9.3 percent. ${ }^{3}$

Racial distrust and dislike within Malaya had long been covered over with a veneer of harmony. The Chinese enjoyed their economic ascendancy, and the Malays felt safe in their political dominancei with Malaysia, the security of the Malays was shaken. The Malays did not immediately realize that their race was no longer in a majority nor even a plurality in Malaysia as it had been in the Federation of Malaya. But when that realization did come, in part with the help of PAP leaders, the resultant fear of a Chinese takeover was shattering. Lee Kuan Yew personified the object of that fear for the Malays.

It is possible that Lee underestimated the intensity of Malay fear of a disruption of the social, economic, and political status quo within which they felt secure, and the vindictiveness with which they would fight to prevent Chinese political dominance. It is possible, on the other hand, that Lee was aware of this but that he was willing to risk inciting the Malays in order to fight, perhaps not solely for his own political power, but for the Malaysia he felt must be. In the final months of the dispute, however, it would appear that supporters of both sides lost sight of reason. Caught up in the sweep of polemics, virtually all the major participants in the dispute--with the probable exception of the Tunkui-failed to foresee, or did not consider to be compe1lingly important, the possible consequences of their words and actions. Yet when the conflict reached its peak, it was probably the fear of racial conflict more than anything else which led to the Tunku's break decision and, ultimately to Lee's acceptance of it.

Issues

As has been pointed out earlier, it is impossible to separate the political from the communal aspects of the dispute. Many of the communal issues crucial to the conflict have been touched upon in the preceding section. A few remain to be dealt with here.

The racial dispute centered around Malay privileges and the PAP's concept of a "Malaysian Malaysia." The PAP was intent on estiblishing a common Malaysian identity among the diverse races of the countryi The party championed a noncommunal or Malaysian Malaysia. As it was described by the

3. Straits Times, June 4, 1965. 
Malaysian Solidarity Convention, "A Malaysian Malaysia means that the nation and the state is not identified with the supremacy, we11-being and the interests of any one particular community or race.t't

A11iance leaders countered that the Alliance had accepted the principle of a Malaysian Malaysia even before Malaysia itself had been formed.t Indeed, the difference between the two points of view as they were expressed publicly appeared to be more in terms of timing and method of approach than in ultimate objective. The difference perhaps can be understood best through the statements of some of the key individuals involved in the dispute. From Lee Kuan Yew:

We both want to get a Malaysian Malaysia, but we propose route "A", direct from many States together into one federation, from manytgroups together into a multiracial party, towards a multi-racial, united Malaysia. They say 'No, let us go slowly--separate States--Singapore different from Malaya. You keep to Singapore, please don't interfere in Malaya. We will run things for you, but we will still try to get to the point of a multi-racial Malaysia. ${ }^{6}$

From MalaysiantMinister of Internal Security and Home Affairs, Dr. Ismail:

There are two ways of establishing a Malaysian Malaysia. First is the platform of the PAP--noncommunalism straight-away. The other--the method adopted by the A11iance--requires two steps. First, inter-racial harmony; second, an ultimate state of non-communalism. $t^{2}$

From the Tunkut

Young men. . I want to rush things. Instead of doing what they want in a quiet and practical way, they tread on everybody's toes, knock everybody's head and bring about chaos, suspicion, misunderstanding, hatred and trouble. . . The suggestion from these young leaders

4. Straits Times, May $10,1965$.

5. Straits Times, June 1, 1965.

6. Straits Times, May 25, 1965 .

7. Straits Times, June 1, 1965. See also Dr. Ismai1's booklet, AlZiance Malaysian MaZaysia in Two Stages (Kuala Lumpur, 1964?). 
is that you can do this [demolish the dividing wal1 among the races] overnight without making any attempt to put the timbers in shape. Why rush? After a11, the nation will live many long years. Why not take time to make a strong nation?

But despite the similarities in rhetoric and ultimate objective, it should be noted that the implications of the two views are distinctly different. Lee's non-communal Malaysia, with all races able to compete for political power on a basis of equality, would most likely result in a predominant1y Chinese government. The Tunku's gradual wearing away of communal walls would assure Malay political control for the present, and perhaps also in the long-run when the Malays reach that theoretical condition of overall readiness to compete with the Chinese from a position of equalityt

A second aspect of the communal dispute centered around Malay rights and privileges. These special privileges had been granted to the Malays in an attempt first, to give them a feeling of security and to compensate, particularly in the political sphere, for the ambition and energy of the chinese; and second, to "uplift" the Malays so that they could eventually compete with the Chinese. Lee attacked Malay privileges on the grounds that they did not achieve their second objective:

While we uphold special privileges for Malays in the constitution, we believe that the crux of the problem is how to raise the living standards of the rural people, who are mainly Malayst Their standards of 1 iving are not advanced by special rights for a small number of special Malays. . . Special privileges will only help a small group of Malay bourgeoisie to become capitalistst who will later exploit the poorer section of the people of a11 races.t

In the words of Singapore Minister for Social Affairs Inche Othman Wok: "The special Malay rights should be an incentive to the Malays to work doubly hard to improve their living and not as an excuse for them to hide behind." $t^{0}$ Lee argued, further, that the Malay privileges provided for in the Constitution were economic and social and not politicalt Thus,

\footnotetext{
8. Straits Times, March 8, 1965.

9. Straits Times, Apri1 29, $1965 t$

10. Straits Times, May 8, 1965.
} 
he maintained, the Malays had no special right to rule Malaysia. ${ }^{1} t$

The Alliance Party supported Malay privileges on the grounds that they did achieve their first objective (to give the Malays security and to compensate for the dynamism of the other communities), and thattthey were absolutely neces sary in order to insure the Malays against domination by the other communities. The Tunku argued:

Our aim to establish a system of parity, not only politically but economically, would leave no one out or unable to compete in the forward march of the new Malaysia. . . Ultimately the time will come when it will be possible by legislative action to amend the Constitution because this special position will no longer be needed. . . It would be foolish, however, to hasten the day of revision of these constitutional rights premature 1 y. 12

Commenting that the Malays constituted only one percent of the business-force and on 1 y 15 percent of the university students, the Tunku warned:

If these rights are taken away what hope is there for the Malays to survive in their own country?... If the Malays are not given protection you will find that they will join the ranks of extremists and in the course of time you will find Malaybia joining Indonet sia. ${ }^{13}$

$\underline{\text { Participants }}$

Two participants in the communal dispute warrant special attention--the Malay "ultras" and the Malay newspaper Utusan Melayu. In the Federation of Malaya and the federation of Malaysia which succeeded it, certain ardent Malay nationalists held important posts in UMNO and in the Alliance. Among the most important were UMNO Secretary General Jaffar Albar, Language and Literature Agency head Syed Nasir, and Minister of Information and Broadcasting Inche Senu, who was also

11. Straits Times, May 27, 1965.

12. Tunku Abdu1 Rahman, "Malaysia: Key Area in Southeast Asia,t' Foreign Affairs, 43:663, July, 1965.

13. Sunday Times (Singapore), April 25, 1965. 
head of the UMNO Youth organizationi It was Lee Kuan Yew who gave these Malay "ultrainationalists" their labe1,14 and perhaps it was also Lee who gave them the means for consolidating their positions and achieving a nationwide following.

It seems evident that the Tunku did make some effort to control the extremists and their precipitant comments. ${ }^{5}$ But the Tunku declined to take any drastic actioniagainst them, and with the absence of his moderating influence during the last two months of the dispute, the ultras became increasing$1 y$ influential in party and government matters. Indeed, the theory has been advanced that at the time of the break, the Tunku was losing his control of the extremists and perhaps also of his party. In an undated letter to Dri Toh, in a lastiminute effort to convince the Singapore Deputy Prime Minister of the necessity of the split, the Tunku wrote:

If I were strong enough and able to exercise complete control of the situation I might perhaps have delayed action, but I am not, and so while I am able to counse 1 tolerance and patience I think the amicable settlement of our differences in this way is the only possible way out.it in $^{6}$

The Tunku subsequently tried to explain that the phrase "if I were strong enough" had no reference to his ability to control his party or the country, ${ }^{7}$ but the inference was clear. Even if one doubts that the Tunku actually was losing control

14. See Lee's interview with Warren Unna reported in the Washington Post, February 5, 1965.

15. A United States Department of State official close to the dispute pointed out, in a personal interview, the unusual silence of Albar and certain other alleged "ultras" following the Singapore riots and after a number of the most heated verbal flare-ups. Further, a Malayan scholar reported that he had read a letter written by the Tunku and sent to the alleged "ultras" immediately before the Tunku left for London in June, 1965. In this letter the Prime Minister instructed his fellow party members to refrain from attacking Lee Kwan Yew or making any statements that might inflame communal passions during the Tunku's absence. The letter itself is unavailable, but its existence has been verified, according to this scholar, by high Alliance party officials.

16. Straits Times, August 11, 1965.

17. Straits Times, August 12, 1965. 
over the ultras, it seems clear that they were taking it upon themselves, with increasing frequency, to speak on behalf of the Malays and that they were quite successful in expressing or encouraging the Malays' fear that their position in the country was being threatened.

Utusan Melayu, a Malay newspaper printed in jawi script also succeeded in exacerbating the communal conflict. The paper printed intensely communal editorials and reported the news with a distinctly Malay-nationalist slant. Perhaps of even greater irritation to Lee and his associates was the fact that the paper, written in a form of Arabic scripts was unintelligible to them except through interpreters. Utusan Melayu reportedly was controlled by certain UMNO leaders, including the Mentri Besar of Trengganu who was the Chairman of the paper's Board of Directors.t

The Dispute

The leaders of the major factions involved in the reaction to and attack on Lee were, as in the 1964 Malayan election campaignt Finance Minister Tan Siew Sin and UMNO Secretary General Jaffar Albar. Intermittent brush fires occurred from the time of merger, but the communal battle began in earnest in Mayt 1965.a. It was then that Lee, by reporting population figures and historical data, made frighteningly clear to the Malays the fact that they were outnumbered by the Chinese, and openly chaltenged the basis of the Malay claim to special status and special privileges. No racial group, said Lee, was any more native than the others:

According to history Malays began totmigrate to Malaysia in noticeable numbers only about 700 years ago. Of the 39 per cent Malays in Malaysia todayt about onet third of them are comparatively new immigrants like the secretary-general of Umnot Dato Syed Ja'afar Albart who came to Malaya from Indonesia just before the war at the age of more than 30. Therefore it is wrong and illogical for a particular racial group to think that they are more justified to be called Malaysians and that the others can become Malaysians only through their favor.t ${ }^{9}$

18. Lee Kuan Yew, The Battle for a Malaysian Malaysia, p. $39 a$

19. Straits Times, May 5, 1965. 
This statement unleashed a barrage of criticisme Albar termed it a "slap in the face of the Malays" and proceeded to spe11 out his own anthropological datae He aceused Lee of being an anti-Malay racist whose loyalty to the concept of Malaysia was questionable, and he warned that if such provoeative statements continued,

I am sure the Malays will lose their patiencee To say that the Malays are 1 ike the other races in this country and that they have no extra right in calling this country their homeland is an insult to the Malay racee It is as if Harry Lee was saying that the Malays were also vagrants, finding shelter in this country. $e^{2}$

UMNO and A11iance units throughout the country refutedeleeds statement as an insult to the Malays and an invitation to communal conflicte

The bitter statement by Razak, second in command of the government of Malaysia, is indicative of the passion of the Malay response to Lee's alleged challenge:

If the people of Singapore wish to maintain this relationship with us, they must find another leader who is sincere. . . Mre Lee has not only upset the Malays, but also the Rulers and everybody else... e Mre Lee does not care what happens to the people so long as he gets into powere We never talk of one community dominating anothere If there is racial trouble, all of us including $\mathrm{Mr}$. Lee, will suffer.e.

Lee reiterated his support for the Constitution, including the provisions for Malay rights, but argued that the constitutional provisions were meant to insure the equal rights of all Malaysian citizens to decide the destiny of the country. He commented that his ancestors went back 100 years in Singapore and ridiculed the idea that Malays of the Malay archipelago, by virtue of their racial origin, are to be considered natives of Malaysiae "If this is so,e' he commented, a11 that President Soekarno need do is to infiltrate more than $4 \frac{1}{4}$ million Indonesians into this country, have a plebise cite, and take over Malaysia as if by righte"12

But further explanations succeeded on $1 y$ in aggravating the situatione Soon the dispute was being carried along with
20. Times (London), May 10, 1965.
21e Straits Times, May 11, 1965.
22 e Straits Times, May 7, 1965. 
a momentum of its own, and no amount of rational analysis or pleas for harmony could stay the vicious polemics of both sidest

The campaign of opposition to Lee took two tracks. The first centered on at-times-absurd extensions of and inferences from Lee's remarks, which led (by design or otherwise) to an intensffication of the conflict and increased fear on the part of the Malays. An editorial in Merdeka, the official organ of UMNO-Malaya, was quoted as having said:

When Lee Kuan Yew denied the right of the Malays and the indigenous people in Malaysia to the ownership of the land, it would follow that Lee has denied the sovereign right to His Majesty the Yang di-Pertuan Agong and all the Malay Rulers. . . A11 the Malays and the indigenous people and loyal citizens of the country wi 11 never forgive him. $\ell^{3}$

From this it was deduced that Lee was trying to get rid of the Malay rulers, and further, that he was not satisfied with Malay special privileges, with Islam as the state religion, or with Malay as the national language. $2^{4}$ Malaysian Malaysia was denounced as being aimed at "destroying the Malay race in its own homeland and destroying Islam and the Islamic State of Malaysia.t't ${ }^{5}$ As the dispute reached its zenith, Inche Senu warned:

The PAP should note that there is a limit to our patience, there is a borderline. . . Push us, corner us . . then the PAP will be responsible for the consequences. . . Do they regard the gentle character of the Malays as a mark of weakness and stupidity? ${ }^{6}$

Lee appeared surprised by these extensions of his remarks and by the hostility they engendered; but he did not (perhaps he could not) back away. He reiterated his support for a non-communal Malaysia, yet, at the same time, he continued to harp on the population figurest with the alleged intention of proving that communal appeals would no longer be effective politically in the new circumstances of Malaysia.t ${ }^{7}$

23a Quoted in Malaysian Mirror, May 22, $1965 a$

24. Straits Times, June 8, 1965 a

25. Quoted inaMalaysian Mirror, July 31 a $1965 \alpha$

$26 a$ Straits Times, June 11, $1965 a$

27. See especially Straids Times, May 24 and June 4, 1965a 
Lee maintained that he was in Malaysia by right and not by anybody's hospitality. Never, he said, had he agreed to Malay rule as a condition for joining Malaysia. In the next 10 to 20 years, the integration of the various races in Malaysia must be achieved so that all would have an equal opportunity to share in the economic, social, and political life of the countryi "The alternative to integration is disintegration, which means calamity for the country as a whole. And it can happen." ${ }^{8}$ And it did happeni

With the mounting racial furor, the call went out for the Central government to take action against Singapore and especially against Lee. The UMNO paper Merdeka asked the Central government to "review Singapore's position in Malaysia" in view of Lee's statements about the Malays.. ${ }^{9}$ Albar was more specifici He opposed banning the PAP but argued that "The authorities should take action against such people, just as they detained the P.M.I.P.'s top leaders. . . "30 Dri Ismail, Minister of Internal Security and Home Affairs, replied at the UMNO general assembly in May that as long as Lee confined himself to speech-making, there were no constitutional grounds forihis detention. The Tunku counseled patience and calm, but it was clear that a substantial portion of UMNO leadership and membership was intent on action to silence. the Singapore leadersi ${ }^{31}$

PAP officials claimed that the ultras had taken over the Alliance machine and that the moderates were having to respond to the antics and manipulations of the ultras.i ${ }^{2}$ In early July, Dri Toh claimed that the Central government had "issued instructions" for a case to be made out for the detention of Lee, and he accused the Central government of placating the extremists $i^{3}{ }^{3}$ Razak replied that the Alliance

28. Straits Times, Ju1y $16 q 1964$.

29. Straits Times, May 8, 1965.

30. Malaysian Mirror, May 8, 1965.

31 It was reported that the UMNO general assembly passed a resolution calling on the Central government to take action to prevent Singapore leaders from continuing to inflame racial passions. See Malaysian Mirror, May 29 , $1965 \alpha$

32. Straits Times, June 9, 1965. It is significant to note, however, that Razak did meet with Lee despite an UMNO Youth ultimatum that he await Lee's apologyi

33. Straits Budget, Ju1y 14, 1965 i 
government did not arrest people without sufficient grounds. $z^{4}$ Said Khir Johari, "We will never make a martyr of the Singapore Prime Ministert All this hope of impending arrest exists only in the minds of the PAP leaders." $2^{5}$ But the tumult over the question of Lee's detention became so great that the Tunku felt it necessary to interrupt his convalescence in London to issue the statement: "As far as I know there is no evidence against $\mathrm{Mr}$. Lee to warrant his arrest or detention." ${ }^{3} \mathfrak{k}$ Yet talk continued.

It is difficult to assess how close to racial violence Malaysia actual1y was at the time of the break. Certainly this was the fundamental reason given by the Tunku for his break decision.t $t^{7}$ It could be that this was simply a rationalization on the part of the Tunku for a decision he wanted to take to remove a political threat and an aggravating nuisance. It seems more likely, however, that the Tunku's fear of impending largetscale racial violence was genuine. Several American officials who were in Malaysia at the time of the break report that communal tension was indeed high, and that a continuation of the dispute at its present intensity might well have restulted in bloodshed. To the Tunkut this would have been the ultimate disaster, the obliteration of all that he had worked for during his political career. Racial violence had to be averted at all cost.

34. Ibid.

35. Straits Budget, July 28, 1965.

$36 \alpha$ Straits Budget, Ju1y 21, $1965 \alpha$

$37 \alpha$ Straits Times, August 10, $1965 \alpha$ 
CHAPTER V

THE FOREIGN VARIANT

The final area of conflict to be considered here was perhaps more a source of irritation, aggravating other more fundamental issues, than an actual cause of the split. This final area includes differences of opinion between the Tunku and Lee on foreign policy matters, and, more important, Lee's remarks abroad and to foreign correspondents which, in the Tunku's eyes, were designed to belittle his regime and himself and to win sympathy and support for Lee in his battle with the Central governmente

The substantive dispute centered around the orientation of Malaysia's foreign policy. Government policy, dictated in part by security considerations, in part by the personal orientation of its leaders, was clearly favorable to the West: The Tunku supported UnitedeStatese actions in Vietnam; $e^{\text {he }}$ frequently expressed his opposition to communism, supported South Korea, and agreed to the establishment of a Nationalist Chinese consulate in Kuala Lumpur in $1964 .^{2}$ The Tunku also was concerned with regional unity and with securing Afroe Asian acceptance for his new federation. $e^{3}$ Yet in the final analysis, something in Malaysia's efforts to align herself with the Afro-Asian world seemed at best half-hearted. Said the Tunku: "We have to mix with peopleesincerely interested in our existencee It is not quite possible to have relations with all the Afro-Asian countries e'é

Lee was far more intent than the Tunku on bringing Malaysia into the Afro-Asian camp. Early in 1964, Lee headed a Malaysian mission to 17 African countries to explain Malaysia's position. On his return he strongly recommended that Malaysia work to consolidate its position in these countriese

1. See Tunku Abdu1 Rahman, op. cit.g especially pp. 667-668.

2. Straits Times, December 17, $\$ 964$.

3. See Willard A. Hanna, "The Importance of Being AfroAsian,e' American Universities Field Staff: Report Service (Southeast Asia), Vo1. 12, Noe 11, December, 1964 .

4. Straits Times, December 17, 1964. 
He argued that isolation from Afro-Asian opinion and identification with imperialist and colonialist nations would mean death for Malaysia: "for us life must mean a growing closer identification with the hopes and aspirations and the political attitudes of the growing band of Afro-Asian and Latin American countries." ${ }^{\circ}$

Lee and his associates opposed blind hostility to communist countries, argued that "some could be useful to us.ín Lee criticized the Western Alliance, $P^{?}$ opposed the establishi ment of a Nationalist Chinese consulate in Kuala Lumpur, $\mathbb{P}^{\oplus}$ criticized U.S. policy in Vietnam, $\stackrel{1}{1}$ and proposed the substitution of Afro-Asian for British troops in the Borneo states.i $i^{10}$

More distressing to the Tunku than the content of Lee's differences of opinion over foreign policy, was the arena in which Lee chose to express them and the reaction of foreign news media to Lee and his statements on both foreign and domestic issues. The Tunku had long been concerned with his own and his countryis international image. He was intent that his country be viewed as happy and prosperous, a mode 1 of multiiracial harmonyi Since the Singapore riots of 1964 , members of the Central government had criticized "biased and inaccurate" stories by foreign correspondents. $1^{1}$ It was as sumed by many that Lee was responsible for the foreign press reports, unfavorable to the Central government, that appeared in many parts of the world. And in a sense, Lee was responsible. He criticiied the Central government freely both at home and abroad. Moreover, as a shrewd debater and a brilliant man, Lee himself was far more attractive to much of the foreign press than the conservative Malay aristocrat who headed the Federal government in Kuala Lumpur.

\footnotetext{
5. Ibid.

6. Straits Times, December 31, $1964 \mathrm{i}$

7. Straits Times, September 8, 1964.

8. Straits Times, December $17,1964 i$

9. Straits Times, March 13, 1965.

10. Straits Times, March 26, 1965.
}

11. See, for example, Straits Times, August 10 and September 7, 1964; and Senu bin Abdul Rahman, The Truth About Us (Kuala Lumpur, 1964). 
Government leaders saw a tendency in the foreign press to build up the Prime Miniseer of Singapore to a position of equal importance with the Prime Minister of Malaysia.e ${ }^{2}$ Foreign correspondents were charged with "smearing" Malaysiaes leaders and "undermining the peoplees confidence in the future of the country. $e^{3}$ Khir Johari accused Singapore leaders, in their interviews with foreign correspondents, of trying to "paint us blacker in order that they would appear whiter.e'li Said Razak, "Seemingly their intention is to create an impression, especially to the outside world, that things are not going well in this country because they are not in control of affairs."15

Lee came under greatest criticism, in this context, for his comments and the reaction to them during his trip to $\mathrm{New}$ Zealand and Auseralia in March and early April of 1965. The editorial comment of the Sydney Morning Herald, March 18 , was typical of the reception Lee received:

in Mr. Lee Kuan Yew, Auseralia welcomes a man who can fairly be ranked as the most able political figure in a11 South-East Asia, shrewd, tough-minded and supremely a realist. Mr. Lee's public mission is to explain Malaysiaes stand and rally support for it. . e . Nobody is better fitted to put Malaysia's case. $e^{6}$

But Malaysian Minister of Commerce and Industry, Dr. Lim Swee Aun, following on Lee's heels in Auseralia (to correct Malaysia's image?) had less complementary things to say. He claimed that Lee had accused the Central government of working only for the Malays and had ridiculed the Tunku for having made a "naive miscake" in thinking that the indigenous people of Borneo were Malaysed?

12. The very similarity of titles of office was unfortunatee In no other area in Malaysia did the head of state hold the title of "Prime Minister,e' and the very terminology created confusion and symbolized a deeper and more fundamental difficulty in the governing of Malaysia. Asked one American diplomat: "How can you have two Prime Ministers in one country and expect it to operate as a unet?"

13. Albar, as reported in Straits Times, February 18, 1965.

14e Sunday Times (Singapore), February 21, 1965e

15. Straits Times, March 3, 1965.

16. Quoted in Malaysian Mirror, Apri1 10, 1965.

17e Straits Times, Apri1 6 and 7, 1965e 
At home the criticism was intense. Lee was accused of having stabbed Malaysia in the back in an attempt to appeal to friendly countries to use their influence to change the political complexion of Malaysia.t ${ }^{8}$ Among the most scathing criticism came from Dr. Ismail who had been, until then, one of the few voices of moderation in the Central government. Lee had projected the PAP image abroad, said Ismail:

This image surrepticiously twists facts and arguments to blacken and smear political opponents. This is the image that cunningly tells foreign correspondents and countries abroad of the fairy tale of how generally backward people are planning to dominate the robust economically advanced Chinese in Malaysia. And if Malaysia breaks up, it is because the communal Alliance is treating the new States in an inferior manner. . . . The PAP is a party that shouts "fire, fire" but commits arson. $t^{9}$

The battle between Lee and the Central government over Lee's statements abroad and to foreign correspondents, reached a climax early in July when the Central government ordered the expulsion of British journalist and long-time Singapore resident, Alex Josey. The action seemed intended as a slap at Lee, since for many years Alex Josey had acted as press relations officer and political confidant to Lee. The original notice of expulsion said only that such action "will be conducive to the good of the Federation."20 But the dispute became so bitter that the Tunku again intert rupted his convalestence in London to explain that Josey had attempted to disrupt racial harmony and to stir up trouble among the races; moreover (and perhaps more to the point), in his efforts to build up Lee's international image, Josey had belittled him (the Tunku) and his race.t ${ }^{1}$

Singapore leaders were furious. Dr. Toh charged that this was the first step towards the suppression of liberalism in Malaysian politics and was an attempt by the Central government to placate the Malay extremists. $2^{2}$ At a farewell

18. Dr. Mahathir in Parliament, reported in straits Times, May 27, 1965.

19. Straits Times, June 1, 1965.

20. Straits Budget, July 14, 1965 .

21. Times (London), July 10, 1965.

22. Ibid. 
dinner given for Josey, the Singapore Minister for Culture, Rajaratnam, commented:

We know that the expulsion of $\mathrm{Mr}$. Josey was a sort of makan kechil [appetizer] to whet the appetite of the extremists for the main dish--the arrest of $\mathrm{Mr}$. Lee, the logical outcome of which must be the arrest and detention of other PAP leaders and eventually all those who do not supinely accept the kind of Malaysia the extremists have in mind. ${ }^{23}$

In its expulsion of Josey, the Central government succeeded only in incurring the wrath of foreign correspondents and news media in many parts of the world. ${ }^{24}$ On the eve of separation, Razak was again appealing to foreign correspondents to give "balanced and fair" accounts of Malaysia from the vantage point of Kuala Lumpur as well as that of Singapore. 25

23. Malaysian Mirror, Ju1y 24, 1965.

24. See especially Times (London) editorial, July 8, 1965, and Canberra Times editorial, July 10, 1965.

25. Straits Budget, August 4, 1965. 
CHAPTER V I

\section{CONTRI BUTING CONDITIONS}

Disagreements over foreign policy and, more importantly, the economic, racial, and political conflicts constitute the major causes of the separation of Singapore from Malaysia. Yet certain other factors made the break decision possible, if not probable.

\section{Singapore Securityt}

The Tunku's primary reason for proposing the formation of Malaysia in 1961 centered upon his fear of communist or extreme leftist ascension to power in the island state and subsequent subversion of Malaya from a Singapore base. The Tunku particularly feared the consequences of an independent Singapore and seemed to feel that the inclusion of Singapore in Malaysia would provide stability and control for Singapore's volatile political climate. That the Tunku was able to make the break decision some four years after his original merger proposal would imply that the Tunku now felt that Singapore's threat to Malaya was greater as a state of Malaysia than as an independent entity. It is clear that the Tunku feared racial violence in Malaysia should Singapore continue as a part of the new federation. But it is also clear that the security situation in Singapore, considered so critical in 1961, had changed sufficiently by 1965 that the threat of communist or extreme leftist control of Singapore was no longer imminent, nor even probable, at least in the near future. This change was due primarily to the action taken by the Singapore and Central governments between 1962 and 1964, against leftist elements in Singapore, resulting in a significant curtailment of the power and potential of the leftist movement in Singapore.

The most obvious arenas of leftist and communist activity in Singapore in the late 1950's and early 1960's were the left-wing political parties (especially the Partai Raayat and the Barisan Socialis party), trade unions and rural

1. For a discussion of the use of the term "security" see footnote 6 , page 5 . The security situation refers to the degree to which "communists" and extreme "leftists" are active and powerful. 
associations (particularly SATU, the Singapore Association of Trade Unions)i, and Chinese educational institutions (notably certain Chinese middle schools and Nanyang University)i. A11 of these became the targets of government interference and attack during the few years immediately preceding and following the establishment of Malaysiai

Early in 1963, in what was known as Operation Cold Storage, about 110 leftist student, union, and political leaders were arrested and detained in Singaporei Those arrested included the Secretary General and Vice Chairman of the Barisan Socialism, the chairman of the Partai Raayat, the Secretary General of SATU, and many others. A number of pro-communist publications also were bannedi These actions were decided upon by the Malayan Internal Security Council, consisting of representatives from Britain, Malaya, and Singapore, in order to "safeguard the defence and security of Singapore and of the territories of the proposed Federation of Malaysia."I

The arrests were carried out by Singapore police assisted by men from the Federation, but Lee was careful to note that the decision to crack down on left-wing elements had not been made by him. At an airport press conference as he returned to Singapore from Kuala Lumpur the day after the arrests, Lee commented that "If it were an action by the Singapore Government, we would never have contemplated it." ${ }^{3}$ He termed the arrests a "regrettable but necessary" step and warned that although the ability of open front communist organizations to mount violent agitation in Singapore had now been "considerably diminished," communist strength in Singapore had not been destroyed.

Riots protesting the Cold Storage detentions occurred in April and again in May, resulting in the arrest of more leftist leaders, particularly the Barisan Socialists. By the time of the Singapore election in September, 1963 i leftist strength, and especially the strength of the Barisan Socialis Party, had been severely undermined. 1

2. See Straits Budget, February 6, 1963.

3. Straits Budget, February 13, 1963.

4. Ibid.

5. The Barisan Socialis Party was formed in mid 1961 by defectors from the PAP over the issue of the terms of merger with Malaya. By mid 1962 , defections from the PAP had become so numerous that the PAP lost its majority in the 
A number of moves against leftist elements in Singapore took place immediately following the 1963 Singapore elections. Students were arrested at Nanyang University for alleged subversive activities. Included among those arrested were three Nanyang graduates who had stood as Barisan candidates in the election a few days before. Proceedings were begun to revoke the citizenship of wealthy Tan Lark Sye, chairman of Nanyang University Council, who was termed by Lee a "stooge to the Communists." $\xi$ The Singapore government also ordered the dissolution of five left-wing organizationst including rural associations and hawkers' unions, in an apparent attempt to reduce "communist" influence in the rural areast ${ }^{7}$ At that timet toot Lee revealed to Malaysian authorities the identity of "the Plen," supposed leader of the communist movement in Singapore. Commented Lee, "Security is no more in my hands." 8

It is interesting to note that in most of the actions taken against leftists in Singapore, both before and after the formation of Malaysia, Lee declined both to take responsibility for and to protest against these moves. It would seem that the Singapore government gladly placed the responsibility for Singapore security in the hands of the Central government, while itself reaping substantial benefit from the decline of leftist strength.

The strikes and labor unrest that plagued Singapore were, according to Lee, symptoms of the disease of communist infiltration, a disease which could be treated only in the context of a wider Malaysia.t Shortly after the formation

Singapore Legistative Assembly. Barisan strength seemed to grow through 1962 , but the party was seriously crippled by the 1963 arrests. For a good discussion of communist activities in Singapore at this time, see Frances L. Starner, "Communism in Malaysia: A Multifront Struggle,t' The Communist Revolution in Asia: Tactics, Goals, and Achievements, Robert A. Scalapinot editor (Englewood Cliffs, N.J., 1965), pp. $246 \mathrm{ff}$.

6. Straits Budget, October 3, 1963.

7. See Osbornet op. cit., pp. 72-73; and Malayan Bulzetin, $17: 3$, October 25, 1963 .

8. Straits Budget, October 2, $1963 t$

9. Straits Budget, March 28, 1962. For statistics on strikes in Singapore see also straits Budget, January 9 and 15 t 1963 . 
of Malaysia, the treatment begane The Barisan-dominated SATU called a strike at the Singapore naval dockyard to begin October 7, 1963, and a two-day general strike to begin the following day. These strikes were called to protest the Singapore government's announced intention to deregister seven unions because of their pro-communist activities. 10 Just as the general strike began, a number of SATU leaders (including three Barison Socialis members of the Singapore Legislative Assemb1y) were arrested and charged with planning acts of violence. The following day, due to the disaffection of several member unions, SATU called off the strike. In Leeds eyes, the communests in Singapore were beaten, at least for the moment.e A month 1 ater the Singapore government official1y refused SATU's two-year-old application for registration and thus made membership in the union illegal.e ${ }^{2}$ Several other left-wingeunions were threatened with cancellation of their registration or found their funds frozen by the Singapore government.

The strength of the Baresan Socialis party, like that of the leftist trade unions, declined after Operation Cold Storagee Late in 1963, three important Barisan leaders were released from detention after signing statements denouncing communism and promising never again to work for a communist cause.e ${ }^{3}$. In May,e 1964, the Barisan Socialis party split into what were termed pro-Peking and pro-Moscow factions.e ${ }^{4}$ The Chairman of the party and leader of the pro-Peking faction, Dre Lee Siew Choh, and certain other members of the executive staff resigned after the defeat of their motion proposing that the Barisan party call for a boycott of national service registratione Though Dre Lee and the other defectors returned to the Barisan Socialis party ten months later, after. an "admission of mistakes" by the interim party leadership, é the scars left by the dispute remained.

In mid 1964, the Central government struck at what Dre Ismail, Malaysian Minister of Internal Security and Home Affaies, called the last bastion of the communists in Singa-

10. See Times (London) and The Guardian, October 9, 1963e

11e Malayan Bulzetin, 17e2, October 25, 1963.

12. Straits Budget, November $20,1963 \mathrm{e}$

13. Straits Budget, December 4, 1963.

14. The Guardian, May 5, 1964e

15. Straits Times, March 9, 1965. 
pore--Nanyang University. More than fifty students were arrested for alleged communist activities. Two weeks later the Malaysian House of Representatives approved a bill requiring al1 students to obtain certificates of suitability from chief education officers before they could be admitted to institutions of higher learning.t ${ }^{6}$

In the spring of $1965 \mathrm{~g}$ the Central government took the last significant pre-break action resulting in the restraint of leftist elements in Singapore. Amid threatened and actual strikes and go-slow campaigns in both Singapore and Malaya, the Central government banned first, go-slow campaigns and later, all forms of industrial action, including strikes, in essential industries and services. The action was taken under the Central government's Emergency powerst and despite the protestations of Singapore officials, the ban was deemed applicable to Singapore as we11 as other parts of the federation.t ${ }^{7}$ Once again, the power of the labor unions, some of which were evidently extremely leftist orientedt was impaired.

It is difficult to determine the exact effect of these measures on the communist and leftist movements in Singapore. Certainly these movements were not destroyed; but equally certainlyt their field of action had been substantially restricted. According to one observert there were indicationst, by 1964 , that mass action through front groups was being abandoned in favor of clandestine activities through under ground satellite organizations.t ${ }^{8}$ A solid core of PAP opponents were under detention; communist and extreme leftist popularity was waning; the arenas of extremist activity were severely restricted. Certainly Singaporets security situation in mid 1965 looked far different than it had looked four years earlier. The major threat to Singapore and Malaysia now seemed to be external (that of Indonesia's Confrontation) rather than internal.

The Tunku had originally opposed the merger of Singapore and Malaya on the grounds that the two societies were too different racially, politicallyt economicallyt and socially. He changed his mind about merger because of what he felt to be the threat posed by Singapore extremists to the security of Malaya. With the elimination or at least the reduction of that threatt and the simultaneous conflict over racial, political, and economic issues, the Tunku seemed to

$16 \alpha$ See Times (London), June 29, and Ju1y 14 and 15, $1964 a$

17. See Straits Times, May 27 and June 18, $1965 \alpha$

18. Starnert op. cit., pp. $232 \mathrm{ff}$. 
return to his original feeling toward merger--that the two entities were simply too different to merge into a single unit.

\section{Other Factors}

Two additional factors may have helped to make the break decision possible, if not probable. First, Malaysia was not a true federation of equal states. The impreciseness of the Constitution, the looseness of the union, and the different status of the different states, combined to make united action extremely difficult. It is not within the scope of this paper to consider all the constitutional ambiguities which undermined the federation of Malaysia. It is hoped that the preceding sections have pointed out some of the manifestations of these difficulties. Suffice it to say that for Malaysia to operate as the unit which both the Tunku and Lee seemedito envision, a considerably tighter, more integrated, and more equipollent union might well have been necessary.

Finally, the Tunku's break decision was possible in mid 1965 because, by that time, Malaysia was an established entity. Malaysia was known and accepted by most of the nations of the world and by the majority of her own citizens.i The dismissal of Singapore from Malaysia, then, would not destroy Malaysia as a concept, as that to which the Tunku had devoted much time, energy, and concern. Even without Singapore, Malaysiaicould live. 


\section{CONCLUSION}

The split, then, was a result of no single conflict, no simple dispute. It grew out of differences in intention and expectation bound up in the very concept of Malaysia. These diffetences were sharpened by divergent economic interests, magnified by conflicting political ambitions, and brought to the point of conflagtation by inter-racial fear.

The Tunku envisioned the new Malaysia as Malaya "writ large, $t$ ' the extension of the political, economic, and social fabric of Malaya to the territories of Singapore, Sabah, and Sarawak. Any changes which were to be made must occur gradually and naturally, over time. Lee Kuan Yew envisioned the new Malaysia as an entirely new entity requiring a different kind of political organization, extensive economic coordination, and a new Malaysian identity. Though he anticipated some resistance to the changes he felt so essential, Lee was convinced that such change must be initiated, through pressure if not by choice.

There were three stages in Lee's campaign to create a Malaysia which would conform to his vision of it. In the first stage, best exemplified by the nature of the PAP's participation in the 1964 Malayan elections, Lee and his Singapore associates attempted to bring about change through cooperation with the Tunku within the established political framework. In the second stage, epitomized by the bitter Budget debate of 1 ate 1964, the PAP worked for change through its assumed role of shrewd but loyal opposition. In the third stage, not clearly divided from the second stage but perhaps best illustrated by the session of the Malaysian Parliament in late May and early June of 1965, Lee pursued his campaign using every means at his command, reasonable and at times unreasonable.

It was frustration rather than design which drew Lee's campaign through these three stages. Could he havetforeseen the ultimate consequences of his efforts, it seems likely that his tactics would have been more moderate, his pressure more subtle. But like many of the politicians on the peninsula, Lee was driven to irrationality by his own determination to achieve that to which he was deeply committed.t

The opposition to the immediate establishment of Lee's envisioned Malaysia, rooted deep in the racial and political realities of Malaya, increased in intensity and emotion as Lee's tactics became more crude, his mission more urgent. 
Stimulus and response, crimination and recrimination grew to such a fevered pitch that it became impossible to determine which side was on offense, which on defense, and the vicious polemics exceeded both the control and the calculations of both sides. In the end, Malaysia became choked with verbiage, plagued with bitterness, disabled by fear. In the Tunku's eyes, separation was the only possible cure by which racial violence could be prevented--an attempt to alleviate the symptoms by isolating the virusi

Malaya and Singapore were bound together with the threads of federation; but the opposing pull of conflicting interests, ambitions, and antagonisms was too strong; the threads of common economic, political, and security interests were too weak, or at the very least, improperly woven together. The fabric of Malaysia could not survive. 



\section{B I BL IOGRAPHY}

\section{A. Books and Collections}

Brackman, Arnold C. Southeast Asia's Second Front: The Power struggle in the Malay Archipelago. New Yorke Frederick A. Praeger, 1966.

Groves, Harry E. The Constitution of Malaysia. Singaporee Malaysia Publications Ltde, 1964 e

Gullick, J. M. Malaya. London: Ernest Benn Ltd., 1963 e

Hanna, Willard A. The Formation of Malaysia: New Factor in World Politicsa New Yorki American Universities Field Staff, 1964 e

- Sequel to Colonalism: The 1957-1260 Foundations for Malaysia. New York: American Universities Field Staff, 1965 .

Indonesia-Malaysia, Problems and Prospects. Selected Readings. Stanford, California: Stanford University, 1964?

Miller, Harrye Prince and Premier. London: George G. Harrap and Company, Ltd., $1959 . e$

Osborne, Milton E. Singapore and Malaysia. Ithaca, New York: Southeast Asia Program, Corne11 University, $1964 \mathrm{e}$

Purcel1, Victore Malaysia. Londone Thames and Hudson, $1965 \mathrm{e}$

Scalapino, Robert A. (ed.)e The Communist Revolution in Asia: Tactics, Goals, and Achievements. Englewood C1iffs, New Jersey: Prentice-Ha11, Ince, 1965e

Sheridan, L.eA. (ed.). Malaya andasingapore, the Borneo Territoaies: The Development of Their Laws and Constitutions. Londone Stevens and Sons Ltd., $196 \notin$.

Silcock, T. H. and E. K. Fisk (eds.)e The Political Economy of Independent Malaya: A Case-Study in Development.

Canberra: Australian National University, 1963 e

Tilman, Robert 0. Bureaucratic Transition in Malaya. Durham, North Carolina: Duke University Press, 1964. 
Wang Gungwu (ed.i). Malaysia: A Survey. Singaporei Donald Moore Books, 1964 .

Wheelwrightj E. L. Industrialization in Malaya. Parkville, Victoria: Melbourne University Press, 1965.

- et a1. The Politics and Economics of Malaysia. Sydneyi Outlook, 1963 .

B. Documents, Official and Semi-Official Publications.

The Alliance. Kuala Lumpuri Alliance Headquarters, 1966.

Goh Keng Swee. Some Problems of Industrialization (Towards Socialism, Vol. 7) . Singapore: Ministry of Culture, 1963 .

Ismail bin Dato Abdul Rahman. AlZiance Malaysian Malaysia in Two Stages. Petaling Jaya, Malaysia: Federal Department of Informationi 1964 .

Lee Kuan Yew. The Battle for a Malaysian Malaysia, No. 1 and No. 2. Singaporei Ministry of Culture, 1965.

. The Battle for Merger. Singaporei Government Printing Office, 1961 .

- The winds of Change. Singapore: PAP Political Bureau, 1964 .

Malaya, Federation of. Parliamentary Debates: Dewan Ra'ayat, Official Report. Kuala Lumpuri Government Printers, 1961-1963.

- Department of Information. Malaysia. Nos. 1-3.

Kuala Lumpuri Department of Information, 1962.

-. Legislature. The Communist Threat to the Federation of Malaya. Legislative Council Paper No. 23 of

1959. Kuala Lumpuri Government Printers, 1959.

Malaysia. Parliamentary Debates: Dewan Ra'ayat, Official Report. Kuala Lumpuri Government Printers, 1963-1965.

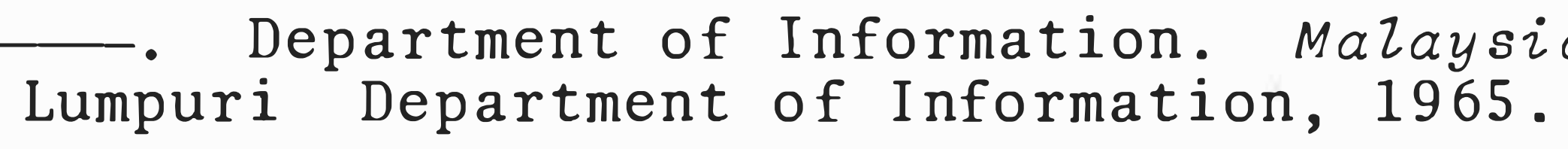


-. Election Commissione Report on the Parliamentary (Dewan Ra'ayat) and State Legislative Assembly General Elections, 1964 of the States of Malayad Kuala Lumpure Government Printers, 1965 .

Malaysia: the Federal Constitutiona Kualaedumpure Government Printers, $1964 \mathrm{e}$

People'seAction Partye Election Manifesto of the P.A.P. Singapore: PAP Political Bureau, 1964.

Souvenir. First Ten Years: P.A.P. 10th Anniversary
l964e

Report on the Economic Aspects of Malaysia by a Mission of the International Bank for Reconstruction and Development. (Rueff Report). Kuala Lumpur: Government Printers, 1963 .

Senu bin Abdu1 Rahman. The Truth About Use Kuala Lumpure Department of Information, $1964 \mathrm{e}$

Singapore, Cmd 22 of 1963. Malaysia: Agreement Coneluded Between the United Kingdom of Great Birtain and Northern Ireland, the Federation of Malaya, North Borneo, Sarawak and Singaporea Singaporee Government Printers, 1963.

Singaporee Economic Development Board. Industrial Opportunities in Singapore. Singaporee Economic Develope ment Board, 1965e

Singapore: Straits Times Press, 1962-1965.

. Ministry of Culture. MaZaysian Heritage. Singaporee Ministry of Culture, $1962 \mathrm{e}$

- Ministry of Culturee The Merger Plana Singaporee Ministry of Culture, 1961.

- Ministry of Culturee Separation. Singaporee Ministry of Culture, $1965 \mathrm{e}$

- Ministry ofeculture. A Year of Decision. Singaporee Ministry of Culture, 1961.

Ministry of Culture. Year of Fulfilment, June
1961-June 1962. Singaporee Ministry of Culture, 1962. 


\section{Articles}

Bochkaryov, Y. "Seceded Bastion, $t$ ' New Times (Moscow), No. 34, August, 1965 , pp. 4-6.

Bottomley, Anthony. "Some Economic Implications" of the Proposed Malaysia Federation from the Point of View of Singapore," The Malayan Economic Review, 7:01-103, October, 1962 .

Boyce, Peter. "Policy Without Authority: Singapore's External Affairs Power," Journal of Southeast Asian History, 6:t87-103, September, 1965 . 21,1965 .

"The Politics of Separation,t' The BulZetin, August and R. K. Davis. "Malaysia Tests the Commonwealth, $t$ ' Australian Quarterly, 37:59-68, September, 1965.

Bradley, C. Paul. "Malaysia's First Year,t' Current History, 48:82-88ff., February, 1965 .

-. "Rupture in Malaysia," Current History, 50:98-105, February, 1966.

Burns, Creighton. "Bombs, Invaders and Race Riots,t' The Age (Melbourne), April 5, $1965 \mathrm{t}$

-. "City of Strife,t' The Age, September 17, 1964.

1965

"Fraying Nerves in Malaysia,t' The Age, July 26,

"Passions in Malaysian Politics,t' The Age, Decemt ber 14,1964 .

1964

"Race Parley in Malaysia,t' The Age, September 25,

- "Singapore P.M.: Young 'Elder Statesman," The Age, March 16, 1965 .

Butwe11, Richard. "Malaysia and Its Impact on the International Relations of Southeast Asia,t" Asian Survey, 4:も40-946, Ju1y, 1964 .

Esslemont, Don. "Politics Before the Split," Venture (London), 17:18-20, September, 1965 . 
FitzGerald, C. P. "The Expulsion of Singapore,1' The Nation, 201:208-212, October, 1965 .

Grossholtz, Jean. "An Exploration of Malaysian Meanings, 1 ' Asian Survey, 6:227-240, Apri1, 1966.

Han Suyin. "Singapore Separation," Far Easdern Economic Revaiew, 49:3349-352, August, 1965.

Hastings, Peter. "Confrontation in Malaysia,1" The Australaian, May $31,1965$.

-. "Race Against Time,i' The Australian, June 1, 1965.

Josey, Alex. "Expelled from Malaysia," New Statesman, July 16,1965, p. 74 .

- "Why Malaysia Failed," New Statesman, August 13, 1965, pp. 207-20B.

Leifer, Michae1. "Communal Violence in Singapore,1' Asian Survey, 4:1115-1121, October, 1964 .

"Politics in Singapore: The First Term of the People's Action Party, 1959-1963,i' Journal of Commonwealth Political Studies, 2:il02-117, May, 1964.

"Singapore in Malaysia: The Politics of Federation,1' Journal of Southeast Asian History, 6:54-70, September, 1965 .

- "Singapore LeavesiMalaysia," The Word Today, 21: 361-364, September, 1965.

"Malaysia: No Bridge Across the Straits,1' The Economist, $214: 326$, January, 1965 .

Milne, R. S. "Malaysia,1' Asian Survey, 4:694-701, February, 1964 .

"Singapore's Exit from Malaysia: The Consequences of Ambiguity,"aAsian Survey, 6:i175-184, March, 1966.

Parmer, J. Norman. "Malaysia 1965: Challenging the Terms of 1957,1' Asian Survey, 6:il11-118, February, 1966.

Rahman, Tunku Abdu1. "Malaysia: Key Area in Southeast Asia,1' Foreign Affairs, 43:659-670, July, 1965.

Roff,i Margaret. "The Malayan Chinese Association, 1948-65, i' Journal of Southeast Asian History, 6:10-53, September, 1965 . 
. "Malaysia Revisited," Australia's Neighbors (Me1bourne), 4 th Series, May-June, 1965, pp. 1-4.

Sheridan, L.tA. "Constitutional Problems of Malaysia," The International and Comparative Law Quarterly, 13:13491367 , October, 1964.

Smark, Petert "A Nation Killed by Racial Hate," The Australian, August 10, 1965.

Smith, T.E. "Malaysia After the Election,t' The World Today, 20:351-357, August, 1964 .

Starner, Frances L. "Malaysia's First Year,t'Asian Survey, $5: \mathbf{t} 13-119$, February, 1965 .

Stockwin, Harveyt "Back from the Brink?," Far Eastern Economic Review, 50:592-594, December, 1965 .

- "Broken Threads in Malaysia,t' Far Eastern Economic Review, 48:118-120, Apri1, 1965.

- - "Crisis in Malaysia,t' Far Eastern Economic Review, 49:187-188, Ju1y, 1965 . - "Economic Fog," Far Eastern Economic Review, 49 :
47, July, 1965.

- "The House Divides, $t$ ' Far Eastern Economic Review, $49: 389-390$, August, 1965 .

- "A House Divided,t' Far Eastern Economic Review, $47: 371-372 \mathrm{ff} . t, \mathrm{March}, 1965$.

- - "Malaysian Approaches,t' Far Eastern Economic Review, 49:252-254, August, 1965.

Tilman, Robert 0. "Malaysiat The Problems of Federation, $t$ ' Western Political Quarterly, 16:899-911, December, 1963.

Topping, Seymour. "Lee Kuan Yew Is Singapore,t' New York Times Magazine, October 31, 1965, pp. 66-68ff.

Tregonning, K. G. "An Interview with a Prime Minister," Australian Quarterly, 37:78-86, December, 1965.

Van der Kroef, Justus Mt "Notes of a New Nation," National Review, 15:390-392, November, 1965.

Vasil, R. K. "Malaya's 'Wild Men,t" Nation, August 21, 1965. 
- "The 1964 General Elections in Malaya," International Studies (New Delhi)e, 7:20-65, July, 1965e

Warner, Denise 'Malaysia: A 'Game of Footsy' in Southeast Asiag" The New Republic, 148:11-12, March, 1963.

- 'The Second Fall of Singapore,e' The Reporter, September 9, 1965, pp. 27-29.e

"Singapore and Malaysia: A Divorce of Inconvenience, $\dot{e}^{\prime}$ ThetReport, Apri1 7, 1966, pp. 44-46e

Wolfsæone, Daniele "The Malays Move In," Far Eastern Economic Review, 42:187-194, October, 1963.

\section{Essays and Articles in Collections}

Goh Keng Sweee "The Economic Problems of Democratic Socia1ism in Malaysia,d' Our First Ten Years, People's Action Partye Singaporee PAP Central Edieorial Board, 1964e Pp. $137-140$.

Hannae Willard A. "The Importance of Being Afro-Asian,é' Southeast Asia Series, Vole 12, Noe 11 (Malaysia). New York: American Universities Field Staff, Service Reports, 1964 e

"The Separation of Singapore from Malaysia," Southeast Asia Series, Vo1. 13, No. 21 (Malaysia). New York: American Universities Field Staff, Service Reports, 1965.

Lee Kuan Yew. "Charting Our Way Forward, é Our First Ten Years, People's Action Party. Singaporee PAP Central Editorial Board, 1964e P. 84.

Lim Kim San. "More Houses for Our People,e' Our First Ten Years, People's Action Party. Singapore: PAP Centra1 Edieorial Board, 1964e Pp. 228-229.

People's Action Party Central Executive Committeee "The First Ten Years: Time for Reflection and Re-assessment,é' Our First Ten Years, People's Action Party. Singapore: PAP Centra1 EdiÆorial Board, 1964. Pp. 109-115.

Rajaratnam, S. "P.A.P.'s First 10 Years,e' Our First Ten Years, People's Action Party. Singapore: PAP Central Edieoria1 Board, 1964. Pp. 204-216e 
Starner, Frances L. "Communism in Malaysia: A Multifront Struggle, $t$ ' The Communist Revolution in Asia: Tactics, Goals, and Achievements, Robert A. Scalapino, editor. Englewood C1iffs, New Jersey: Prentice-Ha11, Inc., 1965. Pp. $221-255$.

Toh Chin Chye. "New Tasks for the PAP, $t$ ' Our First Ten Years, People's Action Party. Singapore: PAP Central Editoria1 Board, 1964. Pp. 125-127a

Wang Cungwu. "The Way Ahead," Straits Times Annual for 1966. Singaporet Straits Times Press, 1965. Pp. 26a31.

Wok, Othman. "Towards One Nation and One Country, $t$ ' Our First Ten Years, People's Action Party. Singapore: PAP Central Editorial Board, 196A. Pp. 242-243a

\section{E. Unpublished Papers}

Boyce, P. J. "Communist Subversion and the Formation of Malaysia.t' Paper presented to Australian National University, Department of International Relationst Seminart Pluralist Elements in Contemporary Communism, August 28 , 1964. (Mimeographed.)

Leifer, Michae1. Malaysia as a Factor in Singapore Politics." Paper presented to the University of London, Institute of Commonwealth Studies, Post Graduate Seminar: Malaysia, January, 1964. (Mimeographed.)

Milne, R. S. "Singapore's Future Prospects." Paper presented at the Center for Southeast Asian Studies, Northern I11inois University, October, 1965.

Ness, Gayle D. "Singapore and Malaysia: Factors in a New Frontier of Conflict in Southeast Asia.t' Paper presented at the Center for Southeast Asian Studies, Northern I11inois University, October, 1965.

Parmer, J. Norman. "The Separation of Singaporet Political Effects in Malaya.t' Paper presented at the Center for Southeast Asian Studies, Northern I11inois University, October, 1965.

Purvist Malcolm J. "The Economic Implications of an Independent Singapore.t' Paper presented at the Center for Southeast Asian Studies, Northern I11inois University, October, 1965. 
Silcock. T. H. "Structured Aspects of Malaysia.e' Paper presented to the University of London, Institute of Commonwealth Studies, Post Graduate Seminar:e Malaysia, November, 1963e (Mimeographed.)

Tilman, Robert 0. "Malaysian Foreign Policy: The Dilemmas of a Committed Neutral.e' Paper prepared for the Asia Society and Association for Asian Studies Conference on "The Foreign Policies of the Southeast Asian States," New York, May 14-15, 1965.

\section{F. Newspapers and Periodicals}

Daily Telegraph (London).

Digest of Press Opinion (Canberra)e

Economist (London)e.

Far Eastern Economic Review (Hong Kong).

The Guardian (London).

Malayan Buzletin (London). (Beginning January, 1964, name changed to Malaysian Bulzetin.)

Malaysian Mirror (Singapore). (Beginning August 14, 1965, name changed to The Mirror.)

New York Times (New York).

Press Release (Washington, D.C.e Embassy of Malaysia)e

Quarterly Economic Review: Malaysia, Brunei (Londone Economist Intelligence Unit Ltd.e). (Title varies according to the status of the countries involved.)

Sari Berita (Kuala Lumpur).

Singapore Trade and Industry (Singapore)e

Straits Budget (Singapore and Kuala Lumpur)e

Straits Times (Singapore and Kuala Lumpur).

Sunday Times (Singapore and Kuala Lumpur).

Times (London). 



\section{APPENDIX I \\ THE TUNKU'S SPEECH ON SINGAPORE'S SEPARATION}

(Full text of speech by the Prime Minister of Malaysia when presenting the Bill amending the Constitution of Malaysia and the Malaysia Act to the House of Representatives on 9 th August 1965.)

What I am about to announce to this House will no doubt cause a big surprise and shock to Hon'ble Members. In fact to me and to many of the members, it is the most painful and heart-breaking news I have had to break and for them to hear it. I consider it a misfortune for me to have to make this announcement. In all the ten years of my leadership of this House, I have never had a duty so unpleasant as this to perform. The announcement which I am making concerns the separation of Singapore from the rest of the Federation.

The reasons for this have been many. Since the formai tion of Malaysia, and this year in particular, there have been so many differences with the Singapore Government and these differencesitake many forms i so much so that it has now come to a breaking point. I canit find any way out except the course of action which I am forced to take.

I have given myself plenty of thoughts while I was lying in bed in London and also when I was convalescing before my return to this country. I had conveyed my thoughts to my friend and colleague, Tun Abdul Razak, who had sought to find an understanding with the leaders of Singapore, but I am afraid to no avail. It appeared that as soon as one issue was resolved, another cropped up. Where a patch was made here, a tear appeared elsewhere, and where one hole was plugged, other leaks appeared. So, it does seem completely impossible to arrive at a solution whereby we can hope to pull along together and to work together in the interest and for the common good of Malaysia. We have tried everything possible to avoid separation of Singapore from the rest of Malaysia. In the end we find that there are only two courses of action open to us.

Number oneiis to take repressive measures against the Singapore Government for the behaviour of some of their leaders and number two to sever all connections with the State Government that has ceased to give even a measure of loyalty to the Central Government. The position of the 
Cientral Government not only at Home but worse still abroad has been mocked on many instances.

It was clear some action must be taken. It is odious for us to take repressive measures against the Singapore Government, for such action is repulsive to our concept of Parliamentary Democracy. Even then it would not solve the problem before us, because as I said just now, there is not one problem but many, and one that gives us the most concern is communal issue. This is the matter which concerns me most, because the peace and happiness of the people in this country depend on goodwill and understanding of the various races for one another. Without it this nation will break up, with consequential disaster which we have seen and read about happening elsewherea We feel that this repressive action against a few would not therefore solve the problem because the seed of this contempt, fear and hatred has been sown in Singapore, and even if we try to prevent its growth, I feel that after a time it will sprout up with a more virulent force $\alpha$ The thousands of students abroad have been fed with al1 kinds of propaganda against the Central Government.

Malaysian Malaysia, in particular, suggests that the Malaysia we have now is bad, for it gives all the advantages to one race while depriving others of their rightful place in our societya

Foreign correspondents who approached me on this subject while I was in England and France were under the wrong impression that the Malay-dominated Central Government has not been fair to othersa, that there has been discrimiation against the Chinese in all fields and in all matters. One even went so far as to suggest that the closing of the Bank of China is a move against the Chinese. Poor stall holders have to close down their stalls because they are unable to get the food they need from China $\alpha$

It was suggested that our quarrel with the P.A.P. was due to the fact that we are afraid of the far more advanced and enlightened socialast Government of Singapore. They appeared incredulous when $I$ informed then that there are Socialist parties in the mainland and other parties who are opposed to our party and the P.A.P. contested our election without success and that the only party that we ban is the Communist Partya I also informed them that most of these parties are made up mainly of Chinese whose number well exceeds that of Mra Lee Kuan Yew's and to suggest, therefore, that $\operatorname{Mr} \alpha$ Lee Kuan Yew represents the Chinese and at the same time represents the only left-wing party in the country is wrong. 
There appeared also in the Foreign Press from time to time, articles and reports which gave an entirely wrong picture of this country to the people abroad. They implied any action that we take to put a stop to the subversive activities of the enemies and traitors as attempts to victimise the Chinese. Apart from the closure of the Bank of China, the resettlement of the Chinese in Sarawak is one of the examples I can give of criticism directed against us. In short while they are trying to build up the image of Lee Kuan Yew they at the same time are belittling us.

While in London I have had to interview some of the pressmen, representing some of the leading papers and maga$z$ ines and explain to them what the position isi but we can't do that all the time. We want to be allowed to be left alone and to be given the moral support which we deserve to bolster our courage against the communist threat and Indonesian confrontation. We consider ourselves as one of the nations in South-East Asia that has managed not only to fight our enemies but also to provide for our people's need. We are in fact one of the countries that have made a real success of our independence.

While weihave to spend so much money in strengthening our defences, we have at the same time managed to provide livelihood, education and other services which have made this country happy and prosperous and the people, on the whole, contented.

There has also been certain inclination on the part of some countries to look upon the Prime Minister of Singapore as an equal partner in the Government of Malaysia and to encourage indirectly to assert his authority and this has made the situation rather awkward for us. In a nation there can only be one national executive head. The illustration which I saw in one of the British papers depicting a cartoon of Lee Kuan Yew and myself over the map of Malaysia, and with the caption "too many cooks" is to the point. This is a situation which we must avoid. There can only be one Prime Minister for the Nation, and so the best course we can take is to allow Lee Kuan Yew to be the Prime Minister of independent Singapore in the full sense of the word which otherwise he would not.

I was hoping to make Singapore the New York of Malaysia and had begged the politicians in Singapore to give their thoughts for the fulfillment of this objective. In order to do that it is necessary to place the interest of Singapore above that of their own personal glorification. Unfortunately political rivalry and political activities and enthusiasm of the various politicians in Singapore had made this impossible. 
They lost sight of the importance of Singapore as one of the most important ports in South East Asia. My dream is shattered and so we come now to the parting of ways.

In the matter of finance, toot it has been extremely difficult to obtain Singapore's support. Criticisms levelled at the Central Government by the Singapore representatives at the last Budget Meeting of this Parliament are still fresh in the Hon'ble Members' memory. Now we find we have reached a stage where it is difficult to agree on anything at a11, however trivial the matter may be. There is disagreement as to the quantum of Singapore's financial contribution to the Centra1 Government.

The Hon'ble Members are aware that there has been a sharp $r i s e$ in the defence and security expenditure and the Central Government felt compelled to ask for Singaporets support. It is only right that it should bear a legitimate share of the country's burden, but Singapore refused to make this contribution except in so far as the Singapore defence is concerned.

Under Annex $J$ to the Malaysia Agreement, Singapore was bound to contribute for a five-year period by way of loan, a sum of $\$ 150 \mathrm{million}$ to the Central Government for economic development in Sabah and Sarawak. Part of this loan was to be free of interest. But this loan has not been given. There have been bickerings over the amount of interest to be paid, and Singapore refused to trust the Bank Negara to determine the current market rates for long-term loans in the Federation, but instead proposed a World Bank arbitrator. This would have taken a considerable time to reach a decision. In the meantime the development of these two States is absolutely urgent.

These are among other troubles we had with Singapore, which as time goes on the political trouble which is simmering today might blow up into something extremely serious.

On the other hand our relationship with Sabah and Sarawak has been excellent. We are desirous of carrying out extensive development programme in these two States, because we realise that under the colonial rule, the development in the two States had been neglected. We know that they have joined us of their own accord and on their own free will in order to enjoy not only the independence and prestige which freedom brings them, but also to enjoy the other fruits of independence.

They fit into the pattern of administration with the rest of the States in Malaysia so admirably we11, and unless 
we can carry out some development, however small it may be, their hope and trust in us will inevitably lessened. But with the money we have to pour out to defend ourselves against Indonesian aggresoion, it was expected that Singapore would co-operate. Unfoetunately they refused.

The people of Sabah and Sarawak live in an area where Indonesian aggression is most strong and violent. Since Indonesia started its confrontation against Malaysia, the people of Sabah and Sarawak have suffered more casualties than the people in the other parts of this countrye In spite of that they feel no fear or sense of frustration but continue to play their part as true, patriotic and loyal citizens of Malaysiae The people in the mainland admire them for their courage and no word is sufficient to describe our thanks and admiration for them.

I hope that the breakaway with Singapore will not cause them undue worry or concern, and that in the circumstances they will agree that the course of action we are taking is the only one open to us in order to maintain peace and harmony in Malaysia, and at the same time to obtain the closest coe operation with Singaporee

Those citizens of Singapore who have been strong in their support for Malaysia, I hope will not feel that they have been let down. I can assure them that in my discussion with the Prime Minister of Singapore we have agreed that they would be given the fullest of protection and amenities as given to the other citizens. On the other hand if they feei strongly that they wish to evacuate and come to the Federation, I have arranged with the Mentri Besar of Johore to reserve quite an extensive area of land in the State to enable them to 1 ive in the Federation. We will do all we can to make them feel confortable and welcome. I pray that they will not lose their sense of balance and do some thing which can only bring about unhappiness to themselves, their famie lies and ourselves. This is the 1 ast thing which we would like to happen, and considering the peace of Malaysia as a whole we are convinced that there is no other way out but to do what we think is best. Things are getting worse every day. Irresponsible utterances are made by both sides, which reading between the 1 ines, is tantamount to challenges, and if trouble were to break out the innocent people will be sacrificed at the altar of belligerent, heartless and irresponsible trouble makers of this country.

So, I believe the second course of action which we are taking, that is the breakaway, is the best and the right one, sad as it may be. We had pledged to form Malaysia with Singapore but having given it a trial we found that if we 
persist in going on with it, in the long run there will be more trouble to Malaysia than what Singapore is worthtto us. The separation will be made on the understanding that we shall co-operate closely on matters of defence, trade and commerce.

This matter was discussed with the Government of Singapore, as a result of which we have drawn up an Agreement which sets out the terms agreed upon and contains those matters which I mentioned just now. This Agreement has been signed by selected members of the Central Government and those of the State Government of Singapore.

The Agreement is to grant Singapore independence and establish it as a sovereign statet [The section of the Tunku's speech dealing with the details of the separation Agreement will be omitted here.]. . .

I pray that Singapore and the people of Singapore will enjoy peace in that island. Whatever we can do to help them, I can assure them that we will be too glad to do. In diversity I am convinced we can find unity or in ordinary every day parlance "absence will make the hearts grow fonder. $t$ "

Notet The Tunku's speech, above, is taken verbatim from Malaysia, Department of Information, Malaysia (Kuala Lumpur, 1965), pp. 53-64. 


\section{APPENDIX I I \\ PROCLAMATION OF SINGAPORE}

free and independent:

WHEREAS it is the inalienable right of a people to be

AND WHEREAS Malaysia was established on the 16 th day of September, 1963, by a federation of existing states of the Federation of Malaya and the States of Sabah, Sarawak and Singapore into one independent and sovereign nation;

AND WHEREAS by an Agreement made on the seventh day of August in the Year one thousand nine hundred and sixty-five between the Government of Malaysia of the one part and the Government of Singapore of the other part it was agreed that Singapore should cease to be a state of Malaysia and should thereupon become an independent and sovereign state and nation separate from and independent of Malaysia;

AND WHEREAS it was also agreed by the parties to the said Agreement that, upon the separation of Singapore from Malaysia, the Government of Malaysia shall relinquish its sovereignty and jurisdiction in respect of Singapore so that the said sovereignty and jurisdiction shall on such relinquishment vest in the Government of Singapore;

AND WHEREAS by a Proclamation dated the ninth day of August in the year one thousand nine hundred and sixty-five the Prime Minister of Malaysia Tunku Abdul Rahman Putra A1Haj Ibni Almarhum Sultan Abdul Hamid Halim Shah did proclaim and declare that Singapore shall on the ninth day of August in the year one thousand nine hundred and sixty-five cease to be a state of Malaysia and shall become an independent and sovereign state and nation separate from and independent of Malaysia and recognised as such by the Government of Malaysia.

Now I LEE KUAN YEW Prime Minister of Singapore, DO HEREBY PROCLAIM AND DECLARE on behalf of the people and the Government of Singapore that as from today the ninth day of August in the year one thousand nine hundred and sixty-five Singapore shall be forever a sovereign democratic and independent nation, founded upon the principles of liberty and 
justice and ever seeking the welfare and happiness of her people in a more just and equal society.

$$
\begin{aligned}
& \text { [signed] } \\
& \text { Lee Kuan Yew } \\
& \text { Prime Minister, Singaporea }
\end{aligned}
$$

Dated the 9 th day of August, 1965.

Note: The Proclamation, above, was taken verbatim from Singapore Ministry of Culture, Separation (Singaporet $1965)$, pp. 1-2. 